Krzysztof Łagojda

[Wrocław]

$\bullet \bullet \bullet \bullet \bullet \bullet$

\title{
Pamięć o ojcu. \\ Refleksje z rozmów \\ z rodzinami katyńskimi. \\ Rekonesans badawczy
}

Wrocławski Rocznik

Historii Mówionej

Rocznik IV, 2014

ISSN 2084-0578

„Życie przegrało ze śmiercią, ale pamięć wygrała w walce z nicością".

Tzvetan Todorov

Od czasu przemian ustrojowych w Polsce słowa „Katyń” i „Zbrodnia Katyńska" należą do kanonu elementarnej wiedzy z historii Polski XX w. Mord sowieckich służb bezpieczeństwa na polskich oficerach ${ }^{1}$ doczekał się wielu wartościowych opracowań, wciąż jednak kilka kwestii wymaga

1 O ofiarach Zbrodni Katyńskiej mówi się najczęściej, że byli to oficerowie Wojska Polskiego. Jest to określenie jak najbardziej trafne, trzeba jednak pamiętać, że byli to przeważnie rezerwiści powołani do służby w sierpniu $1939 \mathrm{r}$. Na co dzień byli urzędnikami, nauczycielami, lekarzami, prawnikami i przedstawicielami innych zawodów. Dla przykładu, w obozie starobielskim na 3895 jeńców tylko 1303 było zawodowymi oficerami w służbie czynnej. Zob.: Dok. nr 20, [w:] Katyń. Dokumenty zbrodni, t. 2: Zagłada. Marzec-czerwiec 1940, oprac. W. Materski i in., Warszawa 1998, s. 74 . 

zbrodni był jednym z najczęściej poruszanych w analizach historii najnow$\mathrm{szej}^{3}$. W imponującej historiografii Zbrodni Katyńskiej brakuje publikacji, które w sposób kompleksowy i z wykorzystaniem aparatu naukowego opisywałyby losy rodzin zamordowanych Polaków ${ }^{4}$.

Celem niniejszych rozważań jest przyjrzenie się wybranym aspektom z życia tych rodzin, poczynając od ostatniego pożegnania z bliskim, który

2 Jednym $\mathrm{z}$ aspektów zbrodni, który nie został jeszcze zbadany, jest tzw. białoruska lista katyńska. Szerzej zob.: S. Kalbarczyk, Białoruska lista katyńska - brakujacy element prawdy o zbrodni katyńskiej, „Zeszyty Katyńskie” 20o8, nr 23, s. 135-145.

3 Z całej literatury przedmiotu wymienić warto: W. Abarinow, Oprawcy z Katynia, Kraków 2007; W. Materski, Katyń. Nasz ból powszedni, Warszawa 2008; Zbrodnia Katyńska. W kręgu prawdy i kłamstwa, red. S. Kalbarczyk, Warszawa 2010; A. Przewoźnik, J. Adamska, Katyń. Zbrodnia, prawda, pamięć, Warszawa 2010; A.K. Kunert, Katyń. Ocalona pamięć, Warszawa 2010; A. Przewoźnik, J. Adamska, Zbrodnia Katyńska. Mord, kłamstwo, pamięć, Kraków 2011; Charków-Katyń-Twer-Bykownia. W 7o. rocznicę zbrodni katyńskiej, red. A. Kola, J. Sziling, Toruń 2011; W. Materski, Katyń. Od ktamstwa ku prawdzie, Warszawa 2012. Nie należy zapominać także o pionierskich pozycjach, które powstały wcześniej: Zbrodnia Katyńska w świetle dokumentów, z przedm. W. Andersa, oprac. J. Mackiewicz, Londyn 1948; J.K. Zawodny, Katyń, Lublin-Paryż 1989; Cz. Madajczyk, Dramat katyński, Warszawa 1989; S. Swianiewicz, W сіеniu Katynia, Warszawa 1990; A. Basak, Historia pewnej mistyfikacji. Zbrodnia katyńska przed Trybunałem Norymberskim, Wrocław 1993; J. Mackiewicz, Katyń - zbrodnia bez sqdu i kary, oprac. J. Trznadel, „Zeszyty Katyńskie” 1997, nr 7; N. Lebiediewa, Katyń. Zbrodnia przeciwko ludzkości, Warszawa 1998. Szerzej zob.: Zbrodnia katyńska. Bibliografia 1940-2010, red. I. Kowalska, E. Pawińska, Warszawa 2010.

4 W nowszych publikacjach o Zbrodni Katyńskiej (zob.: przypis 3) pojawiają się informacje o życiu tych rodzin w kontekście wydarzeń politycznych. Dodatkowo istnieje obszerna literatura traktująca o czterech masowych deportacjach sowieckich (rodziny zamordowanych podlegały kwietniowej deportacji). Jednak nie ma pracy naukowej, całościowo traktującej o losach rodzin pod niemiecką i sowiecką okupacją, a także w PRL. Wyjątek stanowi obroniona w maju 2014 r. w Instytucie Historycznym Uniwersytetu Wrocławskiego praca magisterska autora tego artykułu pt.: W cieniu Zbrodni Katyńskiej. Życie codzienne rodzin oficerskich w latach 1939-1989 w świetle wywiadów z członkami Dolnoślaskiej Rodziny Katyńskiej. Wybrane aspekty, napisana pod kierunkiem prof. dr. hab. Krzysztofa Ruchniewicza. Ciekawą pracę stanowi także opublikowany zbiór 20 wywiadów przeprowadzonych przez Teresę Kaczorowską z synami i córkami zamordowanych Polaków, przy czym nie jest to opracowanie naukowe. Zob.: T. Kaczorowska, Dzieci Katynia, Warszawa 2010. 
wyruszył na wojnę, reakcji na odkrycie przez Niemców grobów w Katyniu w 1943 r., stosunku do tzw. kłamstwa katyńskiego propagowanego w Polsce Ludowej oraz reakcji na ostateczne przyznanie się Związku Sowieckiego do popełnionego mordu. Analiza wywiadów pokaże, przez co przechodziły rodziny zamordowanych Polaków, co z kolei pozwoli spojrzeć na Zbrodnię Katyńską ze znacznie szerszej perspektywy. Badaniem zostało objęte pokolenie córek i synów zamordowanych Polaków ${ }^{5}$. Artykuł nie pretenduje do całościowego ujęcia tematu, a jedynie wskazuje kilka najważniejszych jego aspektów.

Podstawową metodą wykorzystaną w moich badaniach jest oral history, która od lat 90. zyskuje popularność w polskiej nauce 6 . Marta Kurkowska-Budzan, zauważyła, że w tej metodzie pozyskiwania i analizowania źródeł „nie chodzi o wydobycie na światło dzienne nieznanych dokumentom pisanym faktów ani o konfrontację relacji ustnych ze źródłami bardziej wiarygodnymi. [...] Opowieści rozmówców nie pełnią funkcji klasycznego

5 Wszystkie 11 relacji wykorzystanych w niniejszym artykule zebrałem od czerwca 2012 r. do lipca 2013 r. Dotarłem do córek i synów Polaków zamordowanych w Katyniu, Charkowie, Kalininie (obecnie Twer), a także rozstrzelanych na podstawie tej samej decyzji Biura Politycznego KC WKP(b) z 5 marca 1940 r., w więzieniach dzisiejszej Ukrainy i Białorusi. Moi rozmówcy urodzili się w latach 1928-1937. Wszystkie wywiady cytowane w tym artykule odbyły się w ich prywatnych mieszkaniach. Zostały transkrybowane oraz autoryzowane i znajdują się w moim posiadaniu. Wywiady zostały przeprowadzone na potrzeby pracy magisterskiej. Całość obejmuje 19 relacji biograficznych o łącznym czasie 38 godzin. 16 relacji zostało wykorzystanych w pracy magisterskiej.

6 Historię mówioną z punktu widzenia metodologii przedstawia L. Abrams, Oral History Theory, Londyn 2010. W Polsce wciąż brakuje prac traktujących o metodologii historii mówionej w ujęciu historycznym. Jedną z pierwszych badaczek, która w Polsce zasygnalizowała wykorzystanie źródeł mówionych, była Krystyna Kersten. Zob.: K. Kersten, Relacje jako typ źródta historycznego, [w:] Pamiętnik X Powszechnego Zjazdu Historyków Polskich w Lublinie, 17-21 września 1968 r. Referaty plenarne. Sekcje VII-XI, Warszawa 1968, s. 316-329. Pamiętnik dostępny także na stronie Kujawsko-Pomorskiej Biblioteki Cyfrowej: http://kpbc.umk.pl/dlibra/ doccontent $?$ id $=50273 \&$ from $=$ FBC . Oral history jest nadal przede wszystkim metodą badawczą z dziedziny socjologii i antropologii kultury. Obszerniej o perspektywie socjologicznej zob.: P. Filipkowski, Historia mówiona $i$ wojna. Doświadczenie obozu koncentracyjnego w perspektywie narracji biograficznych, Wrocław 2010, s. 21-71. O zbieraniu relacji z perspektywy antropologa kultury zob.: L. Ratkowska-Widlarz, Narracje (relacje świadków) w warsztacie antropologa kultury. Pamięć i antropologia, „Wrocławski Rocznik Historii Mówionej”, R. 1, Wrocław 2011, s. 35-55. 
źródła historycznego. Oral history to historia tu i teraz reprezentowana w ustnej narracji, współtworzonej w dialogu z historykiem"7. Właśnie historia hic et nunc, czyli tu i teraz jest największym zagrożeniem dla wiarygodnej narracji. Co bowiem można zrobić, kiedy świadek, mimo swych najlepszych intencji, kreuje nam swoją wizję przeszłości, opierając się na teraźniejszych osądach i interpretacjach, często także na podstawie nabytej wiedzy książkowej? Historyka nie interesuje obecny stan wiedzy świadka, ale to, co czuł, myślał i robił w przeszłości. Krystyna Kersten trafnie stwierdziła, że czasem nie sposób skontrolować otrzymanych informacji i tylko od ogólnej wiedzy, interpretacji i intuicji historyka zależy, czy uzyskany materiał źródłowy uzna za wartościowy. Biorąc pod uwagę słowa Krystyny Kersten i obecny stan wiedzy o Zbrodni Katyńskiej, a także aktywność rodzin katyńskich ${ }^{9}$ po 1989 r., niniejszy tekst uznać należy za próbę intuicyjnego zdefiniowania, co rodziny czuły, przeżywały i myślały w najważniejszych momentach ich życia. Artykuł nie jest więc próbą odtworzenia wydarzeń historycznych związanych ze Zbrodnią Katyńską sensu stricto.

W trakcie przeprowadzania wywiadów posłużyłem się metodą biograficzną Fritza Schütze ${ }^{10}$, która daje świadkowi możliwość opowiedzenia o tym, co według niego jest w jego biografii istotne. Opisując przebieg swojego życia w swobodnej relacji, świadek staje się bohaterem własnej opowieści, gdyż podążając za myślą wybitnego filozofa i socjologa przełomu XIX i XX w. Floriana Znanieckiego, „[...] każdy człowiek jest ekspertem, najlepszym znawcą swojego świata, i jemu należy oddać głos, jeśli próbujemy przybliżyć się do zrozumienia tego świata" ${ }^{\text {"11 }}$.

W Polsce Ludowej istniał zniekształcony obraz pierwszej połowy XX w. Pamięć Polaków o II Rzeczypospolitej i II wojnie światowej podlegała w PRL manipulacji. Za Barbarą Szacką można scharakteryzować ją

7 M. Kurkowska-Budzan, Antykomunistyczne podziemie zbrojne na Białostocczyźnie. Analiza współczesnej symbolizacji przeszłości, Kraków 2009, s. 32.

$8 \quad$ K. Kersten, Pamięć i uprawianie historii, [w:] eadem, Pisma rozproszone, wybór i oprac. T. Szarota i D. Libionka, Toruń 2005, s. 138.

9 „Rodziny katyńskie” są pojęciem pars pro toto (łac. część za całość). Pod tym pojęciem rozumiemy rodziny Polaków zamordowanych nie tylko w Katyniu, lecz także w Charkowie, Kalininie, Kijowie i innych miejscach byłego ZSRS.

10 F. Maubach, Świadek historii. Swobodne wspominanie a krytyka źródta historycznego - o ambiwalencji metody z zachodnioniemieckiej oral history około roku 1980, „Wrocławski Rocznik Historii Mówionej”, R. 3, Wrocław 2013, s. 52-59; zob.: A. Rokuszewska-Pawełek, Chaos i przymus. Trajektorie wojenne Polaków - analiza biograficzna, Łódź 2002, s. 45-65 i 75-88.

11 Za: P. Filipkowski, op. cit., s. 27. 
jako „pamięć urzędową”" ${ }^{\text {”2 }}$ Według Kai Kaźmierskiej „[...] jest [ona] przede wszystkim kreowana przez instytucje należące do systemu władzy państwowej i lokalnej" ${ }^{\prime 3}$. Okres dwudziestolecia międzywojennego przedstawiany był jako czas nieładu, którego konsekwencją było poddanie się hitlerowskiemu okupantowi. Z tego nieładu, dzięki pomocy Związku Sowieckiego, narodziła się po wojnie nowa socjalistyczna Polska. Druga perspektywa przedstawiała Niemców jako największych wrogów Polski, jedynych winowajców eksterminacji i krzywd narodu polskiego ${ }^{14}$. Narzucenie tej wizji i prześladowania ludzi, którzy występowali przeciwko oficjalnej wersji historii, skutkowały milczeniem na temat tradycji II RP, poszkodowania Polaków przez Związek Sowiecki podczas wojny oraz działalności polskiego podziemia ${ }^{15}$.

Wraz z końcem PRL sytuacja uległa zmianie. Ludzie powoli przełamywali opory oraz strach i zaczynali opowiadać o tym, co ich spotkało. Zmiany polityczne umożliwiły wykorzystanie wywiadów biograficznych w pracach naukowych. W Polsce zaczęto pozyskiwać relacje od osób „wyklętych” przez poprzedni ustrój ${ }^{16}$. Zaliczały się do nich m.in. rodziny katyńskie, które dopiero po 1989 r. mogły swobodnie mówić o swojej tragedii i dochodzić prawdy o Zbrodni Katyńskiej.

W analizowanych wspomnieniach można wyróżnić trzy główne wątki pamięci. Dotyczą one II RP, II wojny światowej oraz Zbrodni Katyńskiej. W niniejszej pracy chciałbym skupić się przede wszystkim na tym ostatnim wątku.

Rzeczą charakterystyczną we wszystkich narracjach jest centralna postać ojca, jako głowy rodziny, wokół której, świadomie lub nie, koncentrują się rodzinne wspomnienia.

Oficerowie Wojska Polskiego w okresie dwudziestolecia międzywojennego byli uznawani za elitę polskiego społeczeństwa. Oficer postrzegany

12 B. Szacka, Czas przeszły, pamięć, mit, Warszawa 2006, s. 153.

13 K. Kaźmierska, Biografia i pamięć. Na przykładzie pokoleniowego doświadczenia ocalonych z zagłady, Kraków 2008, s. 86.

14 B. Szacka, op. cit., s. 154-155.

15 B. Korzeniewski, Transformacja pamięci. Przewartościowania w pamięci przeszłości a wybrane aspekty funkcjonowania dyskursu publicznego o przeszłości w Polsce po 1989 roku, Poznań 2010, s. 78.

16 L. Abrams, op. cit., s. 158; Warto w tym miejscu wspomnieć o inicjatywie ośrodka KARTA z 1987 r., która polegała na zebraniu relacji od osób represjonowanych na Wschodzie, głównie od więźniów łagrów i sybiraków. 
był jako strażnik niepodległości państwa polskiego i uosobienie wszelkich cnót ${ }^{17}$. Taki obraz ojca zachował się w pamięci dzieci oficerów: „Ojciec dbał o dzieci, był dobrym ojcem. Dla niego rodzina była najważniejsza. Bardzo kochał matkę, matka była od niego młodsza o 12 lat, była dla niego świętością. Ja teraz się śmieję z tego, że to był kult jednostki, wszystko można było robić, ale przeciwko matce nie można było słowa jednego powiedzieć. A sam szanował ją bardzo i nie słyszałem, żeby były jakieś sprzeczki domowe", wspomina Adam Zaleski ${ }^{18}$. Obraz rodziny oficerskiej jako idealnej komórki społecznej, w której przekazywane były patriotyczne wartości, przetrwał wiele lat we wspomnieniach dzieci: „Po prostu był to wspaniały dom, pełen miłości, dobra i jakiegoś takiego przygotowania do służenia Polsce. To wychowanie patriotyczne było na co dzień", stwierdziła Alina Głowacka-Szłapowa ${ }^{19}$.

Dzieci oficerów, już jako osoby w podeszłym wieku, z sentymentem i zadumą wspominają idylliczne dzieciństwo, które niespodziewanie dobiegło końca 1 września 1939 r.: „Okres przedwojenny wspominam ze wzruszeniem - opowiada Krystyna Gołębiowska. - Czas spędzony w lesie na zbieraniu jagód, grzybów, przejażdżki łodzią, plażowanie. Tatuś uczył nas jazdy na łyżwach, nartach, na rowerze. [...] Sam projektował kostiumy na bal, malował i rzeźbił. Wieczorami czytał nam książki i opowiadał historię naszej ojczyzny. Rodzice wspominali swoje młode lata i przeżycia w czasie I wojny światowej. Pamiętam defilady i powroty wojska z manewrów [...]. Często mama organizowała nam kinderbale, zapraszała znajomych i dzieci do naszego domu. [...] Byliśmy olśnieni. Beztroskie dzieciństwo skończyło się 1 września 1939 r." ${ }^{20}$. Poczucie bezpieczeństwa dzieci

17 Zob.: F. Kusiak, Życie codzienne oficerów Drugiej Rzeczypospolitej, Warszawa 1992; P. Jaźwiński, Oficerowie i dżentelmeni. Życie prywatne i stużbowe kawalerzystów Drugiej Rzeczypospolitej, Warszawa 2011.

18 Relacja Adama Zaleskiego, syna kpt. Ryszarda Zaleskiego, jeńca Starobielska, zamordowanego przez NKWD w Charkowie wiosną 1940 r. Relacje sporządzone przez Krzysztofa Łagojdę 18 czerwca, 5 września, 13 listopada 2012 r. oraz 9 lipca 2013 r. we Wrocławiu znajdują się w zbiorach własnych autora.

19 Relacja Aliny Głowackiej-Szłapowej, córki kpt. Stanisława Głowackiego, jeńca obozu w Starobielsku, zamordowanego przez NKWD w Charkowie wiosną 1940 r. Relacje sporządzone przez Krzysztofa Łagojdę 9 czerwca, 17 lipca, 17 listopada 2012 r., oraz 8 lipca 2013 r. we Wrocławiu znajdują się w zbiorach własnych autora.

20 Relacja Krystyny Gołębiowskiej, córki mjr. Henryka Zakrzewskiego, jeńca obozu w Starobielsku, zamordowanego przez NKWD w Charkowie wiosną 1940 r. Relacja sporządzona przez Krzysztofa Łagojdę 16 listopada 2012 r. we Wrocławiu znajduje się w zbiorach własnych autora. 
w rodzinnym domu zostało brutalnie przerwane wraz z uderzeniem III Rzeszy i powszechną mobilizacją wojskową, która objęła m.in. ojca Barbary Dworzak: „Małżeństwo mojej mamy było idealne. Moje dzieciństwo, mimo iż krótkie, było przepiękne. W domu było pogodnie i bezpiecznie. Nigdy nie słyszałam podniesionego głosu ojca. Dla mnie wojna to był wstrząs, zawaliło się wszystko, całe życie. Nie było domu, nie było ojca, nie było Polski, nie było języka, szkoły"21.

Wybuch II wojny światowej pozostawił w pamięci tych dzieci trwały ślad, gdyż wtedy ostatni raz widziały swych ojców: „W pamięci pozostała mi scena, jak ojciec pakując się, na wierzchu walizki kładzie rewolwer i zamyka ją - wspominał Jacek Libicki. - To taka jakby fotografia zamykająca pierwszy etap mojego życia. W tym dniu po ojcu w zasadzie ślad się urwał"22. Dzieci, wówczas kilkuletnie, przez wiele lat zachowały w pamięci scenę pożegnania z ojcem, który, jak ojciec Janiny Buczyłko, miał już nigdy do nich nie wrócić: „Kiedy w 1939 r. została ogłoszona mobilizacja, mój tato miał 52 lata. Pamiętam, że siedziałam z mamą w domu [w Pinczowie w woj. kieleckim - przyp. K.Ł.]. Mama wyjrzała przez okno i powiedziała »Chodź, chodź«, wybiegłyśmy przed dom. W tym momencie zobaczyłam, że tata wysiada z jakiegoś auta. Podszedł do nas, pożegnał się i odjechał. To był 3 września 1939 r." ${ }^{23}$. Moi rozmówcy często wracali do najodleglejszych wspomnień. Brak ojca w okresie dzieciństwa skutkował wydobywaniem z pamięci jedynie namiastek, krótkich chwil wspólnie spędzonych, pamiętanych czasem jak przez mgłę: „Była ostatnia Wigilia w 1938 r. Pamiętam, jak rozsunęły się drzwi, ojciec mnie wziął na ręce, wniósł mnie do tego

21 Relacja Barbary Dworzak, córki ekonomisty, por. rezerwy Edwarda Sztarka, jeńca obozu w Kozielsku, zamordowanego przez NKWD w Katyniu wiosną 1940 r. Relacja sporządzona przez Krzysztofa Łagojdę 6 grudnia 2012 r. we Wrocławiu znajduje się w zbiorach własnych autora.

22 Relacja Jacka Libickiego, syna profesora ekonomii, por. rezerwy Janusza Libickiego, jeńca obozu w Kozielsku, zamordowanego przez NKWD w Katyniu wiosną 1940 r. Relacje sporządzone przez Krzysztofa Łagojdę 17 lipca, 4 września, 6 grudnia 2012 r. we Wrocławiu znajdują się w zbiorach własnych autora.

23 Relacja Janiny Buczyłko, córki farmaceuty, por. rezerwy Władysława Błaszczakiewicza, jeńca obozu w Kozielsku, zamordowanego przez NKWD w Katyniu wiosną 1940 r. Relacja sporządzona przez Krzysztofa Łagojdę 28 marca 2013 r. we Wrocławiu znajduje się w zbiorach własnych autora. 
drugiego pokoju, gdzie była zapalona choinka" - opowiadała Wanda Milczanowska, która miała wówczas 3,5 roku $^{24}$.

Pierwsze informacje od głowy rodziny przychodziły już z obozów jenieckich na terenie Związku Sowieckiego ${ }^{25}$. W cenzurowanej przez Sowietów korespondencji jeńcy donosili o swoim zatrzymaniu i niewoli. Źródła epistolograficzne w postaci pocztówek z obozów, a także inne rodzinne pamiątki stanowią pomost między przeszłością a teraźniejszością. Pomagają odtworzyć obraz minionych lat i zachować więź z odległą i bolesną przeszłością. Pamiątki są zarazem swoistymi domowymi relikwiami i „materialnymi nośnikami pamięci rodzinnej oraz weryfikatorami autobiograficznej narracji” ${ }^{26}$, które stymulują wspomnienia z dzieciństwa. Wiadomości z obozów jeszcze dzisiaj wśród moich rozmówców budzą emocje i świadczą o wciąż żywej pamięci tamtych wydarzeń: „Mama tych kartek uczyła się na pamięć, po czym je nam recytowała. Wieczorami, zamiast bajek to słyszałyśmy, co tato napisał i jak to będzie, jak wróci” ${ }^{27}$.

W kwietniu 1940 r. korespondencja z jeńcami obozów nagle się urywa$\mathrm{ła}^{28}$. Rodziny traciły kontakt $\mathrm{z}$ bliskimi. Rozmaitymi sposobami starały się pozyskać jakiekolwiek informacje o ich dalszych losach: „W 1941 r. mama

24 Relacja Wandy Milczanowskiej, córki wiceprokuratora Sądu Okręgowego w Równem na Wołyniu Stanisława Milczanowskiego, zamordowanego przez NKWD wiosną 1940 r. w Kijowie (tzw. ukraińska lista katyńska). Relacja sporządzona przez Krzysztofa Łagojdę 8 lipca 2013 r. we Wrocławiu znajduje się w zbiorach własnych autora.

25 Jeńcy zgodę na korespondencję otrzymali 20 listopada 1939 r. Zob.: Dok. nr 16o, [w:] Katyń. Dokumenty zbrodni, t. 1: Jeńcy niewypowiedzianej wojny. Sierpień $1939-$ marzec 1940, oprac. W. Materski i in., Warszawa 1995, s. 365; S.M. Jankowski, Czterdziestu co godzinę, Warszawa 2001, s. 127. O korespondencji obozowej zob.: S. Jaczyński, Zagłada oficerów Wojska Polskiego na Wschodzie. Wrzesień 1939-maj 194o, Warszawa 2006, s. 187-192. Zob.: ilustrację 1 i 2.

26 B. Szacka, II wojna światowa w pamięci rodzinnej, [w:] P.T. Kwiatkowski i in., Między codziennościa a wielka wojna. Druga wojna światowa w pamięci zbiorowej spoteczeństwa polskiego, Gdańsk-Warszawa 2010, s. 91.

27 Relacja Ludmiły Seredyńskiej, córki nauczyciela historii, por. rezerwy Michała Seredyńskiego, jeńca obozu w Starobielsku, zamordowanego przez NKWD w Charkowie wiosną 1940 r. Relacje sporządzone przez Krzysztofa Łagojdę 21 listopada 2012 r. i 9 lipca 2013 r. we Wrocławiu znajdują się w zbiorach własnych autora.

28 Oficjalnie władze obozowe zakazały korespondencji w połowie marca $1940 \mathrm{r}$. Było to spowodowane decyzją z 5 marca o przygotowaniu obozów do likwidacji. 
poprosiła jedną z Rosjanek, która mieszkała w samym Starobielsku i jechała na urlop do domu, o sprawdzenie, co się w tym obozie dzieje. Wróciła ona z wiadomością, że nikogo nie ma i nikt nic nie wie. Jednak to niczego nie dowodziło"29. Mimo oczywistych obaw rodziny wierzyły, że niedługo kontakt z jeńcami zostanie odnowiony i że ich bliscy wrócą do domów.

Bardzo szybko rozpoczęły one poszukiwania zaginionych poprzez różne organizacje działające jeszcze w czasie okupacji, przede wszystkim Międzynarodowy Czerwony Krzyż ${ }^{30}$. Rodziny, które po ostatecznym podziale Polski 28 września 1939 r. znalazły się w sowieckiej strefie okupacyjnej, 13 kwietnia 1940 r. zostały przymusowo deportowane w głąb ZSRS ${ }^{31}$. Również stamtąd starano się zasięgać jakichkolwiek informacji o losie bliskich: „[...] gdy byliśmy wywiezieni, przeżywaliśmy całą tę katorgę, ale wielokrotnie na zesłaniu wracało się myślą, co z naszymi ojcami się stało. Moja matka zdecydowała się napisać w jesieni 1940 r. do Stalina. Dostała [odpowiedź - przyp. K.Ł.], oczywiście on tego nie czytał, jego sekretariat miał widocznie nakazane odpisać: »Takiego człowieka, Ryszarda Zaleskiego w Związku Sowieckim nie odnaleziono « - taka była odpowiedź" - wspomina Adam Zaleski ${ }^{32}$.

Losy jeńców obozów specjalnych owiane były tajemnicą. Przełomowy okazał się rok 1943, kiedy Niemcy poinformowali o odkryciu masowych grobów jeńców Kozielska w Katyniu. Groby prawdopodobnie już w lipcu 1942 r. odnaleźli i oznaczyli polscy robotnicy przymusowo zatrudnieni w Organizacji Todt (OT), kierując się informacjami przekazanymi przez tamtejszych mieszkańców. Pierwszy komunikat o dokonanym przez NKWD mordzie został oficjalnie ogłoszony w języku angielskim 11 kwietnia 1943 . przez Niemiecką Agencję Informacyjną „Transocean” i był skierowany

29 Relacja Ludmiły Seredyńskiej.

30 Rodziny szybko rozpoczęły poszukiwania swoich bliskich. Poprzez niezależne organizacje starały się zasięgnąć informacji. Zapytania o los bliskiego rodziny kierowały od 1940 r. m.in. do MCK. Zob. ilustrację 3.

31 Decyzja o deportacji rodzin Polaków przetrzymywanych w obozach specjalnych i więzieniach NKWD została podjęta 2 marca 1940 r. na posiedzeniu Rady Komisarzy Ludowych ZSRS. Na mocy uchwały „w sprawie ochrony granicy państwowej w zachodnich obwodach USRS i BSRS” deportacji do Kazachstanu na okres 10 lat podlegało 22-25 tys. rodzin. Zob.: Dok. $n r$ 172, [w:] Deportacje obywateli polskich z Zachodniej Ukrainy i Zachodniej Białorusi w 1940 roku, red. W. Komogorow i in., Warszawa-Moskwa 2003, s. 717 i 719.

32 Relacja Adama Zaleskiego. 
dla słuchaczy poza granicami Rzeszy i krajów okupowanych ${ }^{33}$. Informacje o powziętej na ogromną skalę akcji propagandowej możemy znaleźć w dziennikach ministra oświecenia narodowego i propagandy III Rzeszy Josepha Goebbelsa ${ }^{34}$. Źródło to przedstawia człowieka cynicznego, który bez skrupułów wykorzystuje mord w Katyniu do celów propagandowych. Goebbels stanowczo piętnuje zbrodniczy czyn sowieckiego aparatu bezpieczeństwa na polskiej inteligencji, nie wspominając o zakrojonych na wielką skalę niemieckich akcjach „Inteligencja” i „AB”35. 13 kwietnia Radio Berlin nadało komunikat radiowy dla mieszkańców Generalnego Gubernatorstwa i III Rzeszy ${ }^{36}$. W Generalnym Gubernatorstwie wiadomości o tej tragedii ukazywały się w prasie niemieckiej pisanej w języku polskim, czyli w tzw. gadzinówkach. O Katyniu publikowały m.in. „Nowy Kurier Warszawski”, „Goniec Krakowski” i „Gazeta Lwowska”. W gazetach tych przez pierwsze miesiące od kwietnia 1943 r. pojawiały się także listy nazwisk osób ekshumowanych w Katyniu ${ }^{37}$.

33 A.K. Kunert, „Żotnierze naszej wolności...” Ujawnienie zbrodni katyńskiej 11-15 IV 1943, [w:] Charków-Katyń-Twer-Bykownia. W 70..., s. 15; Obszerniej o propagandzie dotyczącej Katynia zob.: E.C. Król, Polska i Polacy w propagandzie narodowego socjalizmu w Niemczech 1919-1945, Warszawa 2006, s. 411-439.

34 Zob.: J. Goebbels, Dzienniki, t. 3: 1943-1945, oprac. E.C. Król, Warszawa 2014, zapis z 9 kwietnia 1943 r., s. 36. Zapiski dotyczące mordu w Katyniu pojawiają się w dziennikach przez cały kwiecień i sporadycznie także w maju. Jeden z ostatnich wpisów w dziennikach Goebbelsa dotyczący sprawy Katynia pochodzi z 20 maja 1943 r.

35 Szerzej zob.: M. Wardzyńska, Byt rok 1939. Operacja niemieckiej policji bezpieczeństwa w Polsce. Intelligenzaktion, Warszawa 2009; Ausserordentliche Befriedungsaktion 1940. Akcja AB na ziemiach polskich. Materiaty z sesji naukowej (6-7 listopada 1986 r.), red. Z. Mańkowski, Warszawa 1992. O przebiegu akcji AB obszernie traktują dzienniki H. Franka: Okupacja i ruch oporu w dzienniku Hansa Franka 1939-1945, t. 1: 1939-1942, red. Z. Polubiec, Warszawa 1972, s. 158 i nast.

36 Zbrodnia Katyńska w świetle dokumentów..., s. 103-104. Po raz pierwszy książka została wydana w języku polskim w $1948 \mathrm{r}$. w Londynie. W tym samym roku została przygotowana angielska wersja językowa, ale ukazała się ona dopiero w 1965 r. De facto autorem redakcji dokumentów był Józef Mackiewicz, który został jednak pominięty jako autor. Wydał on własną, zmienioną wersję książki. Zob.: K. Zamorski, Autor pierwszej ksiażki o Katyniu, [w:] Szkice nad twórczością Józefa Mackiewicza, red. M. Zybura, Warszawa 1990, s. 131-142.

37 Pierwszy artykuł o niemieckim odkryciu opublikował 14 kwietnia 1943 r. „Nowy Kurier Warszawski”, następnego dnia o mordzie pisał „Goniec Krakowski” i „Gazeta Lwowska”. Obszerniej zob.: G. Szopa, Zbrodnia katyńska w świetle polskojęzycznej prasy okupacyjnej, „Rocznik Historyczno-Archiwalny” 2004, t. 18, s. 121-145. 
Pamięć o tym wydarzeniu wśród rodzin zamordowanych możemy zakwalifikować bez wątpienia do „pamięci zdarzeń specyficznych”, do których zaliczamy m.in. zdarzenia zmieniające dotychczasowe życie człowieka ${ }^{38}$. Oczywiście sam wybuch II wojny światowej był także takim wydarzeniem, ale rozpoczęcie wojny zmieniło życie całego narodu polskiego, natomiast odkrycie grobów w Katyniu - szczególnie tej grupy osób. Rodziny rozstrzelanych Polaków w Katyniu, które słyszały niemieckie doniesienia, dzieliły się na te, które uwierzyły Niemcom, oraz te, które uważały informacje za wymysł nazistowskiej propagandy ${ }^{39}$ : „Wszyscy mówili, żeby nie wierzyć $\mathrm{w}$ te informacje, bo to jest propaganda niemiecka. I my nie wierzyliśmy Niemcom. Uważaliśmy, że to wszystko jest nieprawdą. Nam się to w głowie nie mieściło"4o. Nie chcąc narażać dzieci na stres, matki wolały nie przekazywać im informacji o śmierci ojca, szczególnie jeśli były ich niepewne: „Mama wiedziała, że tata się pojawił na liście - wspomina Janina Buczyłko. - Nam nic nie mówiła. Pamiętam, że szłam z mamą ulicą i podszedł do nas pan, znajomy, i mamie składał kondolencje. Mama bardzo żywo zaprzeczała, że ona w to nie wierzy. Myślę, że mama głównie przy mnie tak zaprzeczała, może jednak w pierwszym momencie rzeczywiście nie wierzyła"41.

Niemożliwe jest przedstawienie w tym miejscu badań statystycznych, które określiły, ile rodzin wierzyło w niemieckie doniesienia z 1943 r. Można jednak zauważyć, że wiele z nich czekało na powrót bliskiego, stąd też słuszny wydaje się wniosek, że początkowo w 1943 r. wiadomości niemieckiej propagandy były traktowane jako kłamstwo. Z drugiej jednak strony pytaniem bez odpowiedzi pozostaje, ile z tych rodzin rzeczywiście wierzyło, że bliskiemu nic się nie stało, a ile poddało się złudnym i irracjonalnym nadziejom. Informacja o domniemanej śmierci członka rodziny mogła wywołać traumę. Tragiczne przeżycie, które dodatkowo nacechowane jest ogromnym ładunkiem emocjonalnym, w ujęciu psychologicznym może bardzo mocno wpływać lub zagrażać tożsamości człowieka. Psychologowie zakładają, że jednostka dotknięta traumatycznym wydarzeniem nie jest

38 T. Maruszewski, Pamięć autobiograficzna, Gdańsk 2005, s. 67-69.

39 K. Łagojda, Niemiecka i sowiecka propaganda o mordzie w Katyniu w świetle wywiadów z dziećmi oficerów Wojska Polskiego, [w:] Stowa w stużbie nienawiści, red. A. Bartuś, Oświęcim 2013, s. 168.

40 Relacja Barbary Dworzak.

41 Relacja Janiny Buczyłko. 
zdolna do racjonalnej interpretacji ${ }^{42}$. Według socjologa Piotra Sztompki, trauma zachodzi m.in. w momencie nagłej i radykalnej zmiany społecznej ${ }^{43}$. O ile w przypadku rodzin katyńskich, wywodzących się z warstwy inteligenckiej, także o tradycjach oficerskich, wojna mogła jawić się jako zmiana ad interim, o tyle wiadomość o śmierci głowy rodziny ugruntowywała i potwierdzała zmianę społeczną, co mogło skutkować wyparciem i niemożnością pogodzenia się z losem. Odpowiadając na pytanie, czy rodziny rzeczywiście nie wierzyły w propagandowe komunikaty, którymi były przecież „karmione” od 1939 r., czy była to raczej reakcja samoobronna na traumatyczne wydarzenie, skłaniałbym się ku drugiej odpowiedzi. Tezę tę zdają się potwierdzać wspomnienia osób, których bliscy przebywali w dwóch pozostałych obozach specjalnych oraz więzieniach NKWD tzw. Zachodniej Ukrainy i Zachodniej Białorusi. Otóż żaden z moich rozmówców z tej grupy nie kwestionował informacji przekazanych przez niemiecką prasę i radio w 1943 r. Osoby te wierzyły, że mord w Katyniu miał miejsce i szukały nazwiska swojego krewnego w gazetach. Okoliczność ta skłania mnie do wniosku, że rodziny (ofiar zamordowanych w Katyniu), które przez wiele miesięcy czy też lat nie wierzyły w wiadomości przekazane przez Niemców, po prostu nie chciały czy też nie mogły pogodzić się ze śmiercią bliskiej osoby.

Janusz Zawodny, świadek kwietniowych wydarzeń, mieszkaniec Warszawy, w swoim pionierskim dziele Katyń zanotował: „Gdy ogłoszono o odkryciu grobów w Katyniu, mieszkałem w Warszawie. Ogół społeczeństwa polskiego przyjmował, że było to goebbelsowskie oszustwo mające na celu wbicie klina pomiędzy Związek Sowiecki i innych Sprzymierzonych"44. W tym kontekście powstaje pytanie, jaką dokładnie liczbę należy rozumieć pod stwierdzeniem „ogół społeczeństwa”, a co ważniejsze, czy tę interpretację dotyczącą całego polskiego społeczeństwa można przenieść na rodziny zamordowanych Polaków? Oczywiście że nie, bowiem poziom emocjonalnego przywiązania do przekazanych informacji był zdecydowanie inny. Rodziny, których bliski nie znajdował się w sowieckiej niewoli, przyjęły tę wiadomość ze smutkiem i częściowym niedowierzaniem, jednak w niedługim czasie wróciły do trosk

42 S. Kapralski, Trauma i pamięć zbiorowa. Przypadek Jedwabnego, [w:] Stawanie się społeczeństwa. Szkice ofiarowane Piotrowi Sztompce z okazji 4o-lecia pracy naukowej, red. A. Flis, Kraków 2006, s. 631.

43 P. Sztompka, Socjologia. Analiza spoteczeństwa, Kraków 2003, s. 456-458.

44 J.K. Zawodny, op. cit., s. 35. 
życia codziennego pod okupacją. Natomiast rodziny, których nazistowska propaganda dotknęła osobiście, musiały mieć do tego wydarzenia zgoła odmienny stosunek.

Inną zastanawiającą kwestią jest, jak długo polskie społeczeństwo i dotknięte rodziny mogły nie wierzyć, że mord w Katyniu miał miejsce? Sam Goebbels zanotował, iż rzeczywiście początkowo polskie społeczeństwo podeszło do przekazanych informacji z dużą dozą nieufności. Z czasem jednak informacje te musiały być uznane za prawdziwe ${ }^{45}$. Jak trafnie ujął to Jacek Chrobaczyński: „Wrażenie katyńskiej hekatomby było w latach 19431944 wszechobecne" ${ }^{\text {"46 }}$. Czesław Madajczyk doszedł do wniosku, że traktowanie przez Polaków Zbrodni Katyńskiej jako mistyfikacji skończyło się wraz $\mathrm{z}$ opublikowaniem $\mathrm{w}$ gazetach zdjęć i nazwisk pomordowanych ${ }^{47}$. Nie do końca zgadzam się z tym stwierdzeniem. De facto „Goniec Krakowski” już 16 kwietnia, czyli w drugim numerze traktującym o zbrodni (pierwsza informacja o mordzie w Katyniu w gazecie pojawiła się 15 kwietnia, zob.: przyp. 37) opublikował pierwszą listę składającą się z 16 nazwisk Polaków zidentyfikowanych w Katyniu ${ }^{48}$. Zdjęcia z miejsca ekshumacji pojawiły się już 17 kwietnia $^{49}$. Wydaje się, że proces przyswajania i pogodzenia się $\mathrm{z}$ otrzymanymi informacjami przebiegał zdecydowanie dłużej ${ }^{50}$. Niemniej jednak wskazanie tutaj jakiejś konkretnej daty jest w mojej ocenie niemożliwe. Nie bez znaczenia były także, pojawiające się w gazetach liczne błędy w nazwiskach i stopniach wojskowych ekshumowanych, które rozbudzały dodatkowe nadzieje.

Mimo przedstawionych wyżej wątpliwości w przeprowadzonych relacjach spotkałem także kategoryczne deklaracje o przyjęciu niemieckiej propagandy za prawdziwą. W tym miejscu nasuwa się kolejne pytanie, o winnego dokonanego mordu. Bez najmniejszej wątpliwości trzeba stwierdzić, że były rodziny, które uważały, że mordu w Katyniu dokonali Niemcy, jednak

Goebbels powołał się na raport SD (Służb Bezpieczeństwa) o nastrojach w Generalnym Gubernatorstwie. Zob.: J. Goebbels, op. cit., zapis z 1 maja 1943 r., s. 61-62.

46 J. Chrobaczyński, Dramatyczny rok 1943. Postawy i zachowania społeczeństwa polskiego w rozstrzygajacym roku II wojny światowej, Rzeszów-Kraków 2012, s. 372.

47 Cz. Madajczyk, op. cit., s. 48.

48 Zob.: „Goniec Krakowski” z 16 kwietnia 1943 r., nr 89. Numery „Gońca Krakowskiego” dostępne są na stronie Jagiellońskiej Biblioteki Cyfrowej: http://jbc.bj.uj.edu.pl/ dlibra/publication $? \mathrm{id}=83 \&$ from $=\&$ dirids $=1 \&$ tab $=1 \& \mathrm{lp}=3 \& \mathrm{QI}=$

49 Zob.: „Goniec Krakowski” z 17 kwietnia 1943 r., nr 90.

50 Zob.: J. Chrobaczyński, op. cit., s. 367-379. 
w relacjach, których wysłuchałem, nie spotkałem się z takim poglądem. Również w analizowanych wspomnieniach o wdowach katyńskich, o których wspominam poniżej, takie przekonania należały do rzadkości. Trzeba jednak wziąć pod uwagę, iż niektóre rodziny w 1943 r. mogły być pewne winy nazistów, jednak $\mathrm{z}$ biegiem lat przeświadczenie to się zmieniło. Dzisiaj wobec powszechnie znanej prawdy, nie pamiętają lub nie chcą pamiętać swoich poglądów sprzed lat. Przywoływanie ludzkich wspomnień było od dawna przedmiotem badań psychologów. Doszli oni do wniosku, że człowiek po latach nie wie, czy to, co relacjonuje, jest odzwierciedleniem własnych przeżyć i myśli z dawnego okresu, czy też wpływ na niego miały opowieści innych świadków ${ }^{51}$. Odróżnienie tych dwóch faktorów jest trudne, żeby nie powiedzieć niemożliwe. Pomijając na chwilę kwestię ludzkiej pamięci i psychologii, wśród rodzin, które wierzyły w mord i które doświadczyły rewolucji w Rosji, czy wojny polsko-bolszewickiej, zauważyłem, iż były one przekonane o winie Związku Sowieckiego: „Nie było cienia wątpliwości. Wiedzieliśmy, że jeńcy wzięci zostali do niewoli przez Rosjan. Poza tym moja mama przeżyła rewolucję 1917 r. w Rosji, bo mieszkała ze swoją rodziną na terenie Ukrainy i znając te stosunki nie miała żadnych wątpliwości co do tego, że jest to autorstwo sowieckie" ${ }_{52}$. Deportowane rodziny, które doświadczyły terroru sowieckiej okupacji, tym mocniej były przekonane o winie NKWD: „Miałem wtedy 15 lat, śledząc bieg wypadków i losy mojego ojca, na 99\% byliśmy pewni, że to zrobili Sowieci. Nie mieliśmy żadnych wątpliwości" - stwierdził Adam Zaleski ${ }^{53}$. Wydaje się, że pewne utarte, negatywne stereotypy przekazywane dzieciom w domu jeszcze przed wojną, miały wpływ na ich interpretacje późniejszych zdarzeń. Jednak biorąc pod uwagę zaszłości historyczne, z drugiej strony trudno mówić tu o stereotypach, a raczej o pewnej tradycji niechęci do wschodniego sąsiada, z którą przecież nie krył się sam marszałek Józef Piłsudski.

Trzeba także mieć na uwadze, że casus Katynia był wydarzeniem bezprecedensowym w historii. Nigdy wcześniej nie doszło na taką skalę do

51 T. Maruszewski, Inflacja wyobraźni jako źródto znieksztatceń pamięci autobiograficznej, „Studia Psychologiczne” 2002, t. 40, nr 1, s. 7-19.

52 Relacja Jacka Libickiego.

53 Relacja Adama Zaleskiego. 
masowego ludobójstwa ${ }^{54}$ osób, które były jeńcami wojennymi. Jak trafnie stwierdził polski socjolog Zygmunt Bauman: „Zagłada była nie tylko czymś złowrogim i zatrważającym, lecz także czymś, co nie dawało się łatwo pojąć w tradycyjnych kategoriach myślenia"s5. Także w wyjątkowości tego zjawiska, można byłoby upatrywać wątpliwości rodzin: „Nam się to w głowie nie mieściło, bo to było chyba pierwsze takie zdarzenie w dziejach, żeby obóz jeńców wojskowych cały zlikwidować"56.

Kwestią wartą refleksji jest wspomniany wyżej stosunek rodzin, których bliski znajdował się w innych niż Kozielsk obozach jenieckich. Niemcy odkryli $8^{57}$ grobów w Katyniu i określili liczbę zamordowanych na około 10-12 tys. Byli przekonani, że w Katyniu odnaleźli całość korpusu oficerskiego poszukiwanego na terenie ZSRR przez rząd RP w Londynie. Szczególnie odkrycie pod koniec prac ekshumacyjnych grobu nr 8 wywołało entuzjazm Niemców, którzy byli przekonani, że odszukali mogiły jeńców Starobielska $^{58}$. W „Gońcu Krakowskim” z 16 kwietnia 1943 r. na pierwszej stronie można było przeczytać: „G.P.U.59 zlikwidowało cały obóz polskich oficerów.

54 Pojęcie ludobójstwa, którego twórcą był wybitny polski prawnik i karnista żydowskiego pochodzenia, Rafał Lemkin, przedstawia mój stosunek do Zbrodni Katyńskiej. Do dzisiaj trwa spór między prawnikami oraz historykami co do tego, czy Zbrodnię Katyńską należy zakwalifikować jako ludobójstwo czy też zbrodnię wojenną. Zob.: M. Kuźniar-Plota, Kwalifikacja prawna Zbrodni Katyńskiej - wybrane zagadnienia, [w:] Zbrodnia Katyńska. W kręu prawdy..., s. 42-51; W. Kulesza, Zbrodnia Katyńska jako akt ludobójstwa (geneza pojęcia), [w:] ibidem, s. 52-67; a także: Zbrodnia Katyńska. Polskie śledztwo, „Zeszyty Katyńskie” 2005, nr 20, s. 9 i nast.; oraz Z. Peszkowski, G. Jędrejek, Zbrodnia katyńska w świetle prawa, Warszawa-Pelplin 2004.

55 Z. Bauman, Nowoczesność i Zagłada, Kraków 2009, s. 8. Pojęcie zagłady użyte w cytacie Zygmunta Baumana odnosi się do zagłady cywilizacji europejskiej w czasie II wojny światowej.

56 Relacja Barbary Dworzak.

57 Ostatni dół nr 8 został odnaleziony 2 czerwca 1943 r., a 7 czerwca ze względu na upały i rój much, prace zostały ostatecznie wstrzymane. Na zakończenie ekshumacji miała również wpływ zmieniająca się sytuacja na froncie wschodnim. Z grobu nr 8 wydobyto ciała jedynie 11 oficerów. Zob.: A. Przewoźnik, J. Adamska, Katyń. Zbrodnia..., s. 241-277.

58 Ibidem, s. 275 .

59 Państwowy Zarząd Polityczny [GPU] (ros. Государственное Политическое Управление; Gosudarstwiennoje Politiczeskoje Uprawlenije) - państwowa policja polityczna w ZSRR, która powstała w lutym 1922 r. na fundamentach bolszewickiej 
$104[\ldots]$ 10.000-12.00o oficerów polskich wymordowanych przez bolszewików”"6o. Informacja o zawyżonej liczbie odnalezionych ofiar skutkowała wykupywaniem i śledzeniem przez rodziny kolejnych numerów gazet $\mathrm{z}$ nowymi nazwiskami ekshumowanych ${ }^{61}$ : „Kiedy Niemcy ogłosili, że w Katyniu jest 10 tys. ofiar, to wszyscy byli przekonani, że jeńcy są z dwóch obozów. W $1943 \mathrm{r}$. Niemcy zaczęli publikować w »gadzinówkach« i ogłaszać nazwiska osób zamordowanych w Katyniu. Była to codzienna lektura i optymistyczna po części, bo na liście pomordowanych mama nie znalazła nazwiska ojca. Wciąż wobec tego żyłyśmy jakąś nadzieją" - zapamiętała Ludmiła Seredyńska ${ }^{62}$. Rodziny żyły nadzieją i wiarą, że ich bliskiego spotkał odmienny los: „Pamiętam takie uczucie ulgi, »nie ma go na liście« [...] mamusia, wujek, ciocia nad jakąś mapą się pochylali, to były mapy wojskowe, niemieckie, gdzie ten Starobielsk, a gdzie ten Katyń, a to w takim razie się uratował, bo on tam nie był, za daleko. To wszystko były takie złudne nadzieje" - wspomina po latach córka jeńca ze Starobielska, Alina Głowacka-Szłapowa ${ }^{63}$.

Rodziny traciły czasem więcej niż jednego bliskiego. Krystyna Gołębiowska wspomina o tragedii, która dotknęła jej matkę: „W 1943 r. jak Niemcy odkryli groby w Katyniu, to mama szukała nazwiska ojca. Z tego względu, że Zakrzewski był popularnym nazwiskiem, do końca nie była pewna, ale w Katyniu zginął również mamy brat, czyli mój wujek, a w Miednoje zginął mamy szwagier. Mama bardzo rozpaczała po śmierci brata, który był tylko dwa lata młodszy. Mama nie miała wątpliwości, kto jest odpowiedzialny za ten mord. Miała nadzieję, że ojca nie spotkał ten sam los i łudziła się, że wróci. Zawsze była iskierka nadziei. Początkowo myśmy nie wierzyli, że już go nie zobaczymy"64.

Czeki w celu zwalczania wewnętrznych i zewnętrznych wrogów Związku Sowieckiego. W 1934 r. jako Główny Zarząd Bezpieczeństwa Państwowego [GUGB] (ros. Главное Управление Государственной Безопастности; Gławnoje Uprawlenije Gosudarstwiennoj Bezopastnosti) włączona w struktury Ludowego Komisariatu Spraw Wewnętrznych [NKWD] (ros. Народный Комиссариат Внутренних Аел; Narodnyj komissariat wnutriennich dieł) - centralnego organu bezpieczeństwa ZSRR.

60 „Goniec Krakowski” z 16 kwietnia 1943 r., nr 89.

61 Do czerwca 1943 r. z grobów w Katyniu wydobyto 4243 ciała, z których zidentyfikowano 2730.

62 Relacja Ludmiły Seredyńskiej.

63 Relacja Aliny Głowackiej-Szłapowej.

64 Relacja Krystyny Gołębiowskiej. 
Niemieckie informacje dotyczące sowieckiego mordu śledziły również rodziny, których bliscy zostali aresztowani na tzw. Zachodniej Ukrainie i Zachodniej Białorusi i do marca 1940 r. przebywali w więzieniach NKWD na tych terenach ${ }^{65}$ : „W momencie odkrycia grobów w Katyniu w 1943 r. szukaliśmy ojca - opowiada Wanda Milczanowska. - Mama i dziadek szukali. Listy były wywieszone na słupach we Lwowie i w gazetach, ale nigdzie tego nazwiska nie znaleźliśmy. Dawało to nadzieję, że gdzieś przebywa, że może się odezwie. Do głowy nam nie przyszło, że podobny los mógł również spotkać ojca"66. Większość rodzin, których bliscy byli aresztowani i przebywali w więzieniach NKWD, nie łączyła mordu w Katyniu z brakiem wiadomości od aresztowanego.

Dwa dni po niemieckim komunikacie, 15 kwietnia 1943 r., strona sowiecka wyparła się wszystkich zarzutów. Przetrwanie koalicji antyhitlerowskiej z ZSRR było dla zachodnich aliantów sprawą priorytetową, dlatego też w momencie ujawnienia grobów przez Niemców Wielka Brytania i Stany Zjednoczone zdecydowały się zachować milczenie ${ }^{67}$. Akcja propagandowa wokół Katynia, nadzorowana przez samego Goebbelsa, urosła do miana największego przedsięwzięcia propagandy narodowego socjalizmu w okresie wojny ${ }^{68}$. Jednak główny cel, jakim było rozbicie koalicji antyhitlerowskiej, nie został osiągnięty.

Wart odnotowania jest stosunek sybiraków do niemieckiego odkrycia w 1943 r., mimo że zebrane na ten temat relacje są niepełne.

Rodziny zamordowanych Polaków podczas kwietniowej deportacji zostały zesłane głównie na tereny Kazachskiej SRS i w większości przypadków nie miały możliwości dowiedzenia się o tym odkryciu. Niektóre z osób deportowanych nie były nawet świadome rozpoczęcia w $1941 \mathrm{r}$. wojny między Związkiem Sowieckim a III Rzeszą, nie wspominając o układzie Sikorski-Majski, który umożliwiał im opuszczenie ZSRR. O stosunku do niemieckiego

65 Polacy przebywający w więzieniach NKWD tzw. Zachodniej Ukrainy i Zachodniej Białorusi na mocy rozkazu Ławrientija Berii z 22 marca 1940 r. zostali przetransportowani do więzień w Kijowie, Charkowie, Chersoniu i Mińsku. Zob.: Dok. nr 27, [w:] Katyń. Dokumenty zbrodni, t. 2.., s. 83-85.

66 Relacja Wandy Milczanowskiej.

67 Zob.: E. Maresch, Katyń 1940. Dowody zdrady Zachodu: Dokumenty z brytyjskich archiwów, Warszawa 2014. Książka została wydana w 2010 r. w Wielkiej Brytanii pod oryginalnym tytułem: Katyn 1940. The Documentary Evidence of the West's Betrayal.

68 J. Goebbels, op. cit., zapis z 8 maja 1943 r., s. 72. 
odkrycia na zesłaniu wspomina Anna Naczke: „Myśmy o niczym nie wiedzieli, nie docierały do nas żadne informacje"69. Wiele zależało od miejsca, do którego rodziny trafiały na zesłanie. Najczęściej były to małe kołchozy i sowchozy odcięte od informacji. Zdarzały się jednak wyjątki: „Mieszkając w mieście wojewódzkim, gdzie można było dostać gazetę, co prawda nie w kioskach, ale, jak wspomniałem były one wywieszane w gablotach. Po drugie była sieć odbiorników radiofonii przewodowej w mieście tzw. »kołchoźników«. Tam gdzie mieszkaliśmy w Semipałatyńsku, miałem gniazdko, mieliśmy słuchawki i cały czas słuchałem radia. Wszystkich komunikatów słuchałem, także jak tylko był komunikat sowiecki, o tym, że Niemcy znaleźli groby katyńskie, na drugi dzień o tym wiedzieliśmy. Wszystko, co TASS pozwolił opublikować, to myśmy wiedzieli. Wszystko, co było w radio, było w gazetach”7o.

Wydaje się jednak, że zesłańcy - o ile dotarły do nich informacje o odkryciu zbrodni - nieco inaczej podchodzili do sowieckiej propagandy. Sami bowiem przeżywali własną tragedię, związaną z deportacją. Każdy dzień był tam nieustanną walką o przetrwanie w ciężkich warunkach ${ }^{71}$ : „Dorośli byli zajęci sprawami bytowymi, pokonywaniem głodu, który tam panował. Ta sprawa [odkrycia grobów w Katyniu - przyp. K.Ł.] nie była tam bardzo głośno rozpatrywana. Zainteresowanie losami naszych ojców cały czas oczywiście było, ale przede wszystkim było zainteresowanie przeżyciem. Ludzie myśleli tylko o tym”72. Potwierdza to również relacja Anny Bocheńskiej: „Jak człowiek był na Syberii, to była walka o przeżycie. Człowiek nie myślał, że wszystko stracił, i dom, i ojca, ojczyzny nie ma. Tam tylko trzeba było pracować, a żeby przeżyć i nie umrzeć z głodu"73.

69 Relacja Anny Naczke, córki starszego przodownika policji państwowej w Wołkowysku Aleksandra Morżało, aresztowanego przez NKWD w październiku 1939 r., przetrzymywanego w więzieniu NKWD w Grodnie. Relacja sporządzona przez Krzysztofa Łagojdę 5 grudnia 2012 r. we Wrocławiu znajduje się w zbiorach własnych autora. Według relacji Anny Naczke, na początku 1940 r. Aleksander Morżało został prawdopodobnie przetransportowany do więzienia w Mińsku. Miejsce śmierci i pochówku nieznane.

70 Relacja Adama Zaleskiego.

71 Obszerniej o życiu Polaków na zesłaniu zob.: S. Ciesielski, Polacy w Kazachstanie w latach 1940-1946. Zesłańcy lat wojny, Wrocław 1996.

72 Relacja Adama Zaleskiego.

73 Relacja Anny Bocheńskiej, córki wójta wsi Tłumacz w woj. stanisławowskim Jakuba Panachidy, zamordowanego przez NKWD wiosną 1940 r. prawdopodobnie w Kijowie (tzw. ukraińska lista katyńska). Relacja sporządzona przez Krzysztofa Łagojdę 8 lipca 2013 r. we Wrocławiu znajduje się w zbiorach własnych autora. 
W przeprowadzonych przeze mnie wywiadach widać pewną prawidłowość: opowieści o 45-letnim powojennym okresie Polski są zdecydowanie uboższe w szczegóły niż te dotyczące 6-letniego okresu II wojny światowej. Może to wynikać z tego, iż jak uważa Marta Kurkowska-Budzan: „Zapominanie [...] to nie efekt oddalenia czasowego od danego zdarzenia - decydujące $\mathrm{w}$ procesie zapamiętywania i zapominania są emocje związane z tym, czego osoba była uczestnikiem lub świadkiem"74. Jeżeli przyjąć właśnie taką definicję zapamiętywania, to wybuch wojny i ogłoszenie grobów w Katyniu należy niewątpliwie uznać za wydarzenia, które budziły bardzo skrajne emocje i są pamiętane przez moich rozmówców do dzisiaj.

Zbrodnia Katyńska oraz pamięć o niej miały swoją historię w PRL. W komunistycznej propagandzie aż do upadku systemu funkcjonowało bowiem tzw. kłamstwo katyńskie ${ }^{75}$. Samo życie codzienne w PRL jest przez te rodziny pamiętane zgoła inaczej. Powołując się na cytowane wyżej słowa Marty Kurkowskiej-Budzan, okres PRL nie wywoływał tak wielkiej gamy emocji, w związku z czym został również zapamiętany bez detali ${ }^{76}$.

W czasie wielkiej fali powrotów do kraju, wśród rodzin, które nie wierzyły w niemieckie doniesienia o Katyniu lub wypierały je ze świadomości, ożyły nadzieje na powrót: „Wiem, że po zakończeniu wojny długo czekaliśmy na powrót taty. Ciągle się czekało i mówiło się o tym, bo ludzie wracali.

74 M. Kurkowska-Budzan, Informator, świadek historii, narrator - kilka wątków epistemologicznych i etycznych oral history, „Wrocławski Rocznik Historii Mówionej”, R. 1, Wrocław 2011, s. 15.

75 Po ogłoszeniu odkrycia przez Niemców masowych grobów polskich oficerów w Katyniu, Związek Sowiecki wyparł się wszystkich zarzutów. Sowieci obarczyli winą Niemców. Według sowieckiej propagandy, mordu mieli dokonać Niemcy w lipcu 1941 r., kiedy to wojska Wehrmachtu zajęły tereny Smoleńska. Zachodnie mocarstwa obawiały się wystąpienia Związku Sowieckiego z koalicji antyhitlerowskiej. Po konferencji w Jałcie i ustaleniu granic powojennej Europy, wszystkie kraje, które znalazły się w strefie wpływów Związku Sowieckiego, były zmuszone przyjąć stalinowską wersję wydarzeń. Obszerniej o kłamstwie katyńskim zob.: F. Kadell, Kłamstwo katyńskie. Historia pewnej manipulacji. Fakty, dokumenty, świadkowie, Wrocław 2008.

76 Na temat wybranych aspektów życia codziennego rodzin katyńskich po wojnie w latach 1945-1989 zob.: K. Łagojda, „Jak tatuś wróci”. Życie codzienne rodzin katyńskich w latach 1945-1989 w świetle wywiadów z członkami Dolnoślaskiej Rodziny Katyńskiej. Studium wybranych aspektów, [w:] Letnia Szkoła Historii Najnowszej 2013. Referaty, red. A.M. Adamus, Ł. Kamiński, Warszawa 2014, s. 53-64. 
108 Ja czekałam bardzo długo, a później śniło mi się długo, że tato wraca"ᄁ7. Rodziny jeńców dwóch pozostałych obozów, o których nie było wieści od 1940 r., chciały wierzyć, że Katyń był odosobnionym miejscem kaźni. Wypieranie prawdy i złudna, ale niezachwiana nadzieja na szczęśliwy powrót bliskiego doprowadzała niejednokrotnie do zachowań nieracjonalnych i pozbawionych logicznych podstaw: „Co wieczór szykowała kolację i biegła na dworzec. Wracali ludzie wynędzniali, ale szczęśliwi, mówili: »Tak, znam takiego, przyjedzie jutro, pojutrze«. Następny wieczór był taki sam, kolejny też. [...] Mama żyła tylko nadzieją, że Ojciec wróci. Znowu biegła na dworzec $^{\text {”78 }}$. Rodziny podejmowały również aktywne poszukiwania: „Myśmy na ojca stale czekali, a potem jak wkraczały wojska, najpierw Armia Czerwona, a potem polska armia, to pamiętam, że wychodziłam przed dom i szukałam ojca. [...]. Mnie się wydawało, że ojciec wróci. Myśmy go szukali w wielu miejscach"79.

Tak samo zachowywały się rodziny, których bliscy trafili do więzień NKWD w tzw. Zachodniej Ukrainie i Zachodniej Białorusi: „Mama już po przyjeździe do Wrocławia, zaczęła ojca szukać poprzez Czerwony Krzyż - wspomina Anna Budzińska. - Wszyscy na ojca czekaliśmy, mimo informacji rozmaitych. Różne informacje krążyły, ale moja mama absolutnie była przekonana, że ojciec żyje. Na biurku stało zdjęcie ojca i mama na ojca czekała. Ponieważ mama na ojca czekała, to ja wiedziałam, że ojciec jest, że on gdzieś żyje, i że on będzie z nami. Mama czekała właściwie do swojej śmierci"so.

Wiara w powrót bliskiego była szczególnie silna w pierwszych latach po wojnie. Każdy dzwonek do drzwi, każdy list rozbudzał nadzieje na spotkanie z mężem lub ojcem ${ }^{81}$ : „Do mnie i do siostry długo nie docierało, że Taty już nie zobaczymy, że po prostu Go nie poznamy. Przez długie lata, słysząc pukanie do drzwi, biegłyśmy z okrzykiem: »To Tato!«, a potem był płacz”»2.

77 Relacja Janiny Buczyłko.

78 Pisane miłością. Losy wdów katyńskich, t. 2, red. A. Spanily, Gdynia 2001, s. 459-46o.

79 Relacja Barbary Dworzak. Zob. ilustrację 4.

80 Relacja Anny Budzińskiej, córki lekarza weterynarii, por. rezerwy Jana Budzińskiego, jeńca obozu w Starobielsku, zamordowanego przez NKWD w Charkowie wiosną 1940 r. Relacje sporządzone przez Krzysztofa Łagojdę 21 listopada 2012 r. i 11 sierpnia 2013 r. we Wrocławiu znajdują się w zbiorach własnych autora.

81 K. Łagojda, „Jak tatuś wróci”. Życie codzienne rodzin katyńskich..., s. 57.

82 Pisane miłością. Losy wdów katyńskich, t. 3, red. A. Spanily, Gdynia 2003, s. 589. 
Moi rozmówcy, wtedy jako dzieci, dziś jako osoby w podeszłym wieku, jednoznacznie stwierdzają, że brak ojca ukształtował i mocno wpłynął na ich dalsze życie: „Kochało się ojca, szanowało, było się przywiązanym. Jestem stara, ale zawsze mi go brakuje. Bez ojca było bardzo ciężko. To się nosi w sercu całe życie, nie ma dnia, żeby człowiek o tym nie myślał"»3. Rodziny bez ojców, którzy zginęli podczas wojny były wówczas zjawiskiem powszechnym, co jednak nie ułatwiało życia rodzinom katyńskim: „Byłam półsierotą, zazdrościłam moim koleżankom, które po maturze szły z ojcem do kawiarni czy na dancing. [...] Rośliśmy z takim garbem psychicznym spowodowanym brakiem ojca i pełnej rodziny" ${ }^{\prime 4}$.

Żony zamordowanych Polaków musiały w powojennej Polsce zorganizować życie w zupełnie nowych i trudnych warunkach, bez wsparcia ze strony męskiej głowy rodziny. Część rodzin przez długie lata wyczekiwała rychłego powrotu bliskiego: „Moja mama wierzyła aż do 1986 r. [do śmierci - przyp. K.Ł.], że ojciec wróci i mama podtrzymywała tę wiarę. Co chwilę się słyszało, że żołnierze wracają. Czyli czekanie było od 1939 r. do 1986 r. w przypadku mamy. Nigdy nie wyszła za mąż. Wszystko było uwarunkowane »jak tatuś wróci«" ${ }^{85}$. Kwestia ponownego zamążpójścia wśród żon zamordowanych Polaków jest zagadnieniem również wymagającym kilku słów wyjaśnienia. Aby żona mogła starać się o ponowne małżeństwo, musiała najpierw złożyć wniosek do sądu o uznanie osoby zaginionej za zmarłą (zakaz bigamii). Regulował to art. $8 \mathbb{\$} 1$ prawa małżeńskiego ${ }^{86}$. Dopiero po uzyskaniu stosowanego postanowienia można było wejść w nowy związek małżeński. Nie rozwiązywano małżeństw osób uznanych za zmarłe, bo-

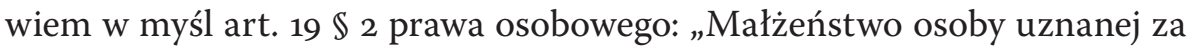
zmarłą rozwiązuje się z chwilą zawarcia przez jej współmałżonka nowego małżeństwa"87. Takie zaświadczenie było potrzebne rodzinom m.in. do uzyskania renty po zmarłym, a dla dzieci dodatkowego stypendium socjalnego w momencie rozpoczęcia studiów. Temat starania się żon o uznanie Polaków z trzech obozów specjalnych za zmarłych, jest osobną, znacznie

83 Relacja Barbary Dworzak.

84 Relacja Wandy Milczanowskiej.

85 Relacja Aliny Głowackiej-Szłapowej.

86 Prawo osobowe. Postępowanie o ubezwtasnowolnienie, postepowanie o uznanie za zmarłego i stwierdzenie zgonu, oprac. I. Różański, Kraków 1946, s. 78.

87 Ibidem, s. 77. 
110 bardziej skomplikowaną kwestią, która w tym miejscu została jedynie zasygnalizowana ${ }^{88}$. Abstrahując od motywów, którymi kierowały się rodziny występując do sądu, bardzo interesującym aspektem jest samo ponowne wyjście za mąż żon zamordowanych oficerów, lub wybranie życia w samotności. Mimo świadomości, że nie uda mi się przedstawić pełnych wyników statystycznych, zdecydowałem się na przeanalizowanie dostępnych źródeł, w celu wskazania głównej tendencji w kwestii ponownego zamążpójścia kobiet wcześniej związanych z oficerami. Poniższa tabela wskazuje cząstkowe wyniki przeprowadzonych badań.

TABELA 1. Wykaz liczbowy dotyczący ponownego zamążpójścia żon zamordowanych oficerów.

\begin{tabular}{|c|c|c|c|c|}
\hline & Ankiety & Wywiady & Wspomnienia & Razem \\
\hline Ogółem & 64 & $14(2)^{89}$ & 131 & 209 \\
\hline Tak & 13 & 1 & $20^{90}$ & 34 \\
\hline Nie & 51 & 13 & $111^{91}$ & 175 \\
\hline
\end{tabular}

ŹRÓDŁO: Kolumna „Ankiety” oparta jest na ankietach pozyskanych od Dolnośląskiej Rodziny Katyńskiej, które zostały złożone przez żony oficerów w momencie wstąpienia do dolnośląskiego stowarzyszenia po 1989 r. Wyniki w kolumnie „Wspomnienia” pozyskałem, analizując tomy Pisane miłością. Losy wdów katyńskich, red. A. Spanily, t. 1-3, wydane w Gdyni w 2000, 2001 i 2003 r.

88 Więcej o temacie uznania za zmarłego przez sądy w PRL zob.: L. Kocoń, Zaginieni 1939-1945. Postępowania o uznanie za zmartego i stwierdzenie zgonu, t. 1 - powiat tomżyński, Białystok 2008, oraz B. Samarski, Zaginieni 1939-1945. W świetle akt Sqdu Grodzkiego w Białymstoku, t. 2 - powiat białostocki, Białystok 2011.

89 Liczba w nawiasie oznacza wyłączone z badania wywiady, gdyż matki moich rozmówców zginęły w czasie wojny.

90 Spośród 20 kobiet, które ponownie wyszły za mąż, 9 było żonami oficerów zamordowanych w Katyniu.

91 Spośród 111 kobiet, które nie wyszły ponownie za mąż, 42 były żonami oficerów zamordowanych w Katyniu. 
Spośród wszystkich przeanalizowanych 209 przypadków, tylko 34 kobiety wyszły ponownie za mąż, co daje wynik $16 \%{ }^{92}$.

Wiara i przekonanie o tym, że bliski przeżył wojnę i wróci, z biegiem lat słabły, szczególnie u dzieci, które zakładały własne rodziny: „Z czasem przestało się oczekiwać, że wróci - relacjonuje Alina Głowacka-Szłapowa. - W 1940 r. dostaliśmy te dwie kartki ze Starobielska. No i co dalej? Tutaj jest już rok 1948, 1950, już prawie 10 lat, jeszcze można było oczekiwać,

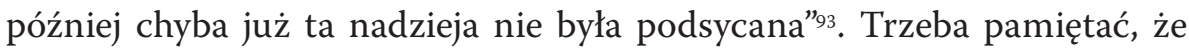
pokolenie, którego dzieciństwo przypadło na lata 30. i początek II wojny światowej, szybciej dojrzewało. Brak męskiej głowy rodziny doprowadził do emancypacji kobiet, ale także dzieci. Załamał się patriarchalny model wychowania, szczególnie częsty w rodzinach oficerskich okresu międzywojnia. Kobiety wraz z opuszczeniem domu przez męża stały się odpowiedzialne za swoich bliskich. Także dzieci od najmłodszych lat uczyły się samodzielności ${ }^{94}$. Było to pokłosie wojny, która tę zmianę wymusiła: „Po wojnie byliśmy zaabsorbowani kształtowaniem swojego życia tutaj w kraju. Tworzeniem rodziny, domu, osiąganiem cenzusów naukowych, kształceniem dzieci. To był dla nas najważniejszy cel. [...] Pytanie o los ojca było cały czas aktualne, ale ono zawisło w próżni. Nie było z kim o tym rozmawiać, może dlatego nie rozmawialiśmy na co dzień o tym [...]. Po prostu

92 Oczywiście dane te są niepełne wobec tysięcy wdów po zamordowanych ofiarach. Nie można wykluczyć, że na taki wynik wpływ również miał wiek kobiet po zakończeniu II wojny światowej. Trzeba także pamiętać, że kobiety te wywodziły się z inteligencji. W czasach II RP rzeczą naturalną był dobór partnera wywodzącego się z tej samej warstwy społecznej. Według Krystyny Kersten po wojnie osób z wyższym wykształceniem było nie więcej niż zaledwie 65 tys. Zob.: K. Kersten, Polskiego inteligenta życie po śmierci, [w:] eadem, Pisma rozproszone..., s. 54. Takich czynników wpływających na wynik było bardzo dużo i nie sposób dzisiaj ocenić, ile z tych kobiet rzeczywiście czekało na powrót męża i nie zdecydowało się na ponowne małżeństwo, mimo wielu propozycji. W analizowanych wspomnieniach widać jednak, że kobiety po wojnie chciały przede wszystkim pomóc swoim dzieciom w dalszej drodze życiowej. Zamieszkiwały razem z nimi, wychowywały wnuki i zajmowały się domem, czyli robiły to, do czego były przyzwyczajone w okresie dwudziestolecia międzywojennego.

93 Relacja Aliny Głowackiej-Szłapowej.

94 M. Zaremba, Wielka trwoga. Polska 1944-1947. Ludowa reakcja na kryzys, Kraków 2012, s. 128. 
112 byliśmy zajęci bez reszty budową swojego prywatnego życia i przyszłości”95. Osoby, z którymi rozmawiałem, były świadome zmiany, jakie zaszły w ich młodym życiu: „To mnie ukształtowało [wojna - przyp. K.Ł.], umiałam sobie dać w życiu radę, nie będąc agresywną, ale dbając o zdobycie tego, do czego byłam zobowiązana" ${ }^{\prime \prime}$.

Bez względu na to, czy rodziny wierzyły w powrót swojego bliskiego, czy też nie, i jak bardzo ich życie po wojnie się zmieniło, wszystkie kultywowały o nim pamięć. Wspominanie męża i ojca było częścią życia codziennego, najczęściej przy okazji świąt: „Najgorsze dla mnie były jednak święta, Boże Narodzenie i Wielkanoc. Był nakryty stół i fotografia taty w ramce na stole. To były zawsze smutne święta. [...]. Mamusia bardzo pilnowała, żeby zachować wszystkie dokumenty i zdjęcia ojca. Jak się gdzieś przenosiliśmy, to zawsze na pierwszym miejscu było pakowanie tych dokumentów, zdjęć, dyplomów, orderów. Wszystko, co przypominało nam o ojcu" ${ }^{\text {97 }}$. Nie bez znaczenia dla tych rodzin był także dzień 1 listopada, obchodzony w PRL jako Święto Zmarłych. Mimo iż los ich bliskich był nieznany, a dla niektórych nie do zaakceptowania, i mimo że nie było znane miejsce złożenia szczątków bliskiej osoby, cmentarz był miejscem wspomnień i zadumy nad losem członka rodziny. Pełnił także funkcję symbolicznego miejsca jego spoczynku. Jacek Kolbuszewski stwierdził, że: „Jak gdyby w nawiązaniu do tradycji dawnego prawa cmentarnego azylu, cmentarze - a wraz z nimi pogrzeby - nieformalnie (nawet gdy to były cmentarze komunalne) wyłączone zostały z jurysdykcji oficjalnych władz i zostały niejako »zawłaszczone « przez opozycję - przez naród”88. Na cmentarzach, jeszcze w okresie komunistycznej cenzury zaczęły pojawiać się symboliczne nagrobki, epitafia i krzyże, które upamiętniały zamordowanych i zaginionych Polaków99: „Mamusia umarła jak powiedziałam w 1986 i ja chcąc jakoś upamiętnić tatę, na grobie mamusi dałam taki napis: »Wdowa po Stanisławie Głowackim kapitanie 38 pp. w Przemyślu zaginionym w 1940 r. w Starobielsku«"'100.

Pamięć rodzin oficerskich o II RP, represjach Związku Sowieckiego i zbrodni w Katyniu była sprzeczna z komunistyczną propagandą. Podlegała zafałszowaniu, czy wręcz eliminacji. Ministerstwo Bezpieczeństwa

95 Relacja Adama Zaleskiego.

96 Relacja Aliny Głowackiej-Szłapowej.

97 Ibidem.

98 J. Kolbuszewski, Cmentarze, Wrocław 1996, s. 12.

99 Ibidem.

100 Relacja Aliny Głowackiej-Szłapowej. Zob. ilustrację 5. 
Publicznego w marcu 1952 r. wystosowało rozporządzenie nr 6/52, w którym osoby propagujące „oszczercze informacje” wymierzone w Związek Sowiecki w sprawie Zbrodni Katyńskiej, lub słuchające zagranicznych audycji, w których były podawane informacje o mordzie, miały być aresztowane i pociągnięte do odpowiedzialności ${ }^{101}$.

W PRL wypełnianie ankiet i pisanie życiorysów było dla rodzin osób zamordowanych w Katyniu sprawą kłopotliwą. Istotnym pytaniem było, czy pisać zgodnie z sumieniem i własnymi przekonaniami, narażając się na prześladowania, czy wypełniać pisma kłamliwymi, komunistycznymi wskazówkami: „Pytali mnie o ojca, to powiedziałam, że zginął w Katyniu, ale nie wypowiadałam się, kto to zrobił. Wiadomo było, że to Niemcy zrobili, nie było innej wersji" "102 . Najczęściej osoby pytane odpowiadały neutralnie: „Zaginął podczas wojny”.

Poprzez groźby i strach władze komunistyczne starały się ugruntować pamięć o mordzie w Katyniu zgodnie z komunistyczną wykładnią. Taka polityka miała również na celu wyciszenie sprawy mordu ${ }^{103}$. Sama atmosfera terroru, szczególnie w latach 1948-1956, powodowała niechęć i strach przed poruszaniem tych kwestii: „W PRL-u mówiono, że to oczywiście Niemcy zrobili, bo tak twierdziła komisja Burdenki ${ }^{104}$ [...]. Te sprawy nie były do końca wyjaśnione, więc rozmawiało się tylko w domu. Każdy się

101 A. Przewoźnik, Proces odkrywania prawdy i upamiętniania ofiar, [w:] Białe plamy - czarne plamy. Sprawy trudne w relacjach polsko-rosyjskich (1918-20o8), red. A.D. Rotfeld i A.W. Torkunow, Warszawa 2010, s. 301.

102 Relacja Janiny Buczyłko.

103 Obszerniej o prześladowaniach w PRL zob.: P. Gasztold-Seń, Siła przeciw prawdzie. Represje aparatu bezpieczeństwa PRL wobec osób kwestionujacych oficjalna wersję Zbrodni Katyńskiej, [w:] Zbrodnia Katyńska. W kręgu prawdy..., s. 132-153; M. Golon, Zbrodnia katyńska w propagandzie PRL (1944-1989). 45 lat fatszowania historii, [w:] Charków-Katyń-Twer. W sześćdziesiątą rocznicę zbrodni, red. A. Kola, J. Sziling, Toruń 2001, s. 24-64; idem, Kary za prawdę o zbrodni Stalina. Represje polskich organów bezpieczeństwa w okresie stalinowskim (1944-1956) wobec osób ujawniajacych władze ZSRR jako sprawców zbrodni katyńskiej w świetle inwentarza dokumentacji przechowywanej w zasobie archiwalnym Instytutu Pamięci Narodowej, [w:] Charków-Katyń-Twer-Bykownia. W 70..., s. 225-240.

104 Sowiecka komisja śledcza utworzona 13 stycznia 1944 r. przez Biuro Polityczne KC WKP(b). Celem komisji, której przewodniczącym został Nikołaj Burdenko, neurochirurg, naczelny lekarz Armii Czerwonej, było udowodnienie tezy popartej sfabrykowanymi dowodami, że zbrodni w Katyniu dokonali żołnierze Wehrmachtu latem 1941 r. Więcej o komisji pisze: N. Lebiediewa, Komisja specjalna i jej przewodniczący Burdenko, „Zeszyty Katyńskie” 20o8, nr 23, s. 56-101. 
bał. Nie rozmawiało się o tym nawet między bliskimi znajomymi. Jak była mowa o ojcu, to mówiło się, że zginął podczas wojny i tyle"105. Również dzieci, które nie znały losów swojego ojca, były przestrzegane, aby o nim nie rozmawiać. O atmosferze strachu na początku lat 50. wspomina Anna Budzińska: „Kiedy byłam starsza, zaczęłam pytać [o ojca - przyp. K.Ł.]. Mama z babcią odbyły ze mną rozmowę, żeby mówić, że ojciec nie wrócił z wojny i tak wypełniać wszelkie pisma czy ankiety, bo nie znaliśmy jego prawdziwego losu. [...] Matka się bała, że to może mieć konsekwencje niedobre dla niej, dla pracy, dla życia. To były jeszcze czasy dziwne. W pięćdziesiątych latach ludzie nagle znikali, byli wywożeni, mama się bardzo bała"106.

Sprzeczna z oficjalną pamięć o Zbrodni Katyńskiej została w PRL zepchnięta do podziemia. Wyjaśnienie zbrodni było niemożliwe, a próby prowadziły do prześladowań ze strony aparatu bezpieczeństwa. Paradoksalnie jednak podjęte przez komunistów w Polsce próby wymazania terminu „Katyń" z polskiego słownika, przyczyniły się do jeszcze większego kultywowania osobistej pamięci o ofiarach tej zbrodni. Jak słusznie stwierdził Bartosz Korzeniewski, „wydarzenia wykluczone całkiem z obiegu oficjalnego okazywały się być również tymi, które stanowiły najbardziej trwałe elementy obrazu przeszłości narodowej kultywowanego w pamięci nieoficjalnej"107. Już pod koniec lat 4o., w dobie stalinizmu, polskie społeczeństwo dawało wyraz swojej dezaprobacie wobec oficjalnej polityki władz w sprawie Katynia. W biuletynach dziennych Ministerstwa Bezpieczeństwa Publicznego odnotowywano przejawy wrogiej agitacji względem Związku Sowieckiego i domagania się prawdy o Katyniu ${ }^{108}$. Takich akcji wymierzonych przeciwko władzy i oficjalnej polityce historycznej było znacznie więcej. Nasilały się przede wszystkim w czasie przełomów politycznych ${ }^{109}$.

Pamięć o Katyniu przetrwała długie lata komunistycznego ustroju, pielęgnowana i przekazywana dalej w domowym zaciszu. W przypadku rodzin katyńskich pamięć domowa zadziałała niczym tama, która blokowała przedostanie się z zewnątrz informacji fałszywych i nasiąkniętych

\footnotetext{
105 Relacja Barbary Dworzak.

106 Relacja Anny Budzińskiej.

107 B. Korzeniewski, op. cit., s. 79.

108 Biuletyny dzienne Ministerstwa Bezpieczeństwa Publicznego 1949-1950, wybór i oprac. Ł. Kamiński, Warszawa 2004, s. 221.

109 Biuletyny Komitetu do spraw Bezpieczeństwa Publicznego. Grudzień 1954 - listopad 1956, oprac. W. Chudzik i in., Warszawa 2009, s. 695.
} 
komunistyczną propagandą, pełną przekłamań i przemilczeńn ${ }^{110}$. Warto w kilku zdaniach skupić się na roli rodziny w przetrwaniu pamięci o ojcu, mimo wielu lat zakłamywania historii. Socjologowie doszli do wniosku, że wydarzenia wielkiej historii na stałe zagościły w pamięci rodzinnej, szczególnie pokolenia II wojny światowej ${ }^{111}$. W każdej rodzinie bowiem była osoba, która brała udział w ważnych wydarzeniach historycznych, co było tematem wielogodzinnych rozmów i wspomnień. Nie inaczej było w przypadku rodzin katyńskich. Ojciec i mąż brał udział w wojnie obronnej 1939 r., bronił niepodległości kraju, dostał się do niewoli i poniósł śmierć. Wśród rodzin oficerów, o niezwykle silnych tradycjach patriotycznych i niepodległościowych, takie rozmowy nie były czymś wymuszonym, ale naturalnym.

Według badań opinii publicznej, przeprowadzonych w Warszawie przez Centrum Badań Opinii Społecznej (CBOS) w lipcu 1988 r., aż 49,5\% dorosłych respondentów za winnych zbrodni w Katyniu wskazało Związek Sowiecki, wśród młodzieży ten odsetek był jeszcze wyższy i wyniósł $68,4 \%$. Tylko 6,5\% dorosłych i 9,3\% młodzieży odpowiedziało, że winnymi zbrodni w Katyniu są Niemcy ${ }^{112}$. Sondaż pokazał, że polityka oparta na zastraszaniu, represjach i fałszowaniu pamięci poniosła klęskę. Polacy nie tylko nie zapomnieli, co wydarzyło się w Katyniu, lecz w większości przypadków doskonale zdawali sobie sprawę z tego, kto tej zbrodni dokonał.

Dzieci oficerów, które z biegiem lat zakładały własne rodziny, dbały o to, aby zaszczepić w swoim potomstwie wiedzę o dziadku. W ten sposób informacje o ofiarach Zbrodni Katyńskiej były przekazywane z pokolenia na pokolenie: „Starałem się przekazywać pamięć o moim ojcu mojej rodzinie, żonie i synom. Moi synowie mimo, iż urodzili się w czasach PRL-u doskonale wiedzieli, co to jest władza komunistyczna, totalitaryzm, więc byli odpowiednio wychowani i przygotowani" ${ }^{{ }_{113}}$.

Zwycięstwo „Solidarności” w Polsce w 1989 r. oraz przeobrażenia w Związku Radzieckim związane z pierestrojką były sygnałem nadchodzących zmian również w sprawie Zbrodni Katyńskiej. Nadszedł czas, aby

110 K. Kersten, Pamięć $i$..., s. 142.

111 B. Szacka, II wojna światowa w pamięci..., s. 93-96.

112 Opinia publiczna o zbrodni w Katyniu. Komunikat z badań, Warszawa 1988, s. 5. Można oczywiście zarzucić, że badania zostały przeprowadzone dopiero w 1988 r., i nie są one miarodajne w stosunku do świadomości Polaków w początkowych latach Polski Ludowej.

113 Relacja Adama Zaleskiego. 
ostatecznie wyjaśnić kwestie „białych plam” w historii Związku Sowieckiego i innych krajów bloku wschodniego ${ }^{114}$. W opracowaniu przygotowanym przez Ministerstwo Spraw Zagranicznych ZSRR z lutego 1989 r. czytamy: „Ze szczególną ostrością wystąpił problem »białych plam« w historii naszych stosunków z kilkoma krajami socjalistycznymi. Chodzi tu o wątpliwości dotyczące radziecko-niemieckiego paktu z 1939 r., »sprawy katyńskiej«, wydarzeń z 1956 r. na Węgrzech, kryzysu w Czechosłowacji w 1968 r. i innych. Odwlekanie prac nad oceną tych wydarzeń z pozycji »nowego myślenia« wywołuje rozdrażnienie w określonych kręgach społecznych zainteresowanych krajów i owocuje brakiem zaufania różnych warstw społeczeństwa do naszej polityki"115.

Przeobrażenia polityczne 1989 r. znacząco wpłynęły na przemiany pamięci społeczeństwa polskiego. Ze względu na społeczny kontekst wyróżniamy trzy wymiary pamięci: pamięć zbiorową, pamięć biograficzną, nazywaną też jednostkową, oraz pamięć społeczną określonej zbiorowości ${ }^{116}$. W przypadku pamięci rodzin katyńskich do 1989 r. możemy mówić tylko o pierwszych dwóch wymiarach. Lata 1945-1989 to walka pamięci zbiorowej, oficjalnej czy urzędowej z pamięcią biograficzną. Spotkania rodzin, zawiązywanie kół i stowarzyszeń po 1989 r., sprzyjały narodzinom pamięci społecznej, kreowanej przez instytucje obywatelskie. Pamięć jednostek została wówczas włączona w pamięć społeczeństwa rodzin katyńskich i stała się podstawą nowej pamięci zbiorowej. W 1990 r. ruszył powolny proces odkrywania tajemnic Zbrodni Katyńskiej i do dzisiaj rodziny zamordowanych Polaków inicjują i wspierają kultywowanie pamięci o tym wydarzeniu.

17 grudnia 1991 r. Sąd Wojewódzki we Wrocławiu oficjalnie zatwierdził powstanie stowarzyszenia Dolnośląska Rodzina Katyńska ${ }^{117}$. Statut tej organizacji wymienia 7 celów, z których najistotniejsze jest ujawnienie i utrwalenie w pamięci polskiego społeczeństwa prawdziwych losów obywateli, którzy po wkroczeniu Armii Czerwonej na tereny Polski znaleźli się w obozach jenieckich i wiosną 1940 r. zostali rozstrzelani w Katyniu i innych miejscach

114 Zob.: Rosja a Katyń, red. A. Dzienkiewicz, Warszawa 2010.

115 Dok. nr 4o, [w:] Polska 1986-1989: koniec systemu, t. 3, red. A. Dudek i A. Friszke, Warszawa 2002, s. 229.

116 K. Kaźmierska, op. cit., s. 86.

117 Postanowienie Sądu Wojewódzkiego we Wrocławiu o sygnaturze I 1 Ns Rej. st. 131/91 z dnia 17 grudnia 1991 roku. 
byłego ZSRR ${ }^{118}$. Kultywowanie tej pamięci wśród członków stowarzyszenia przejawia się przede wszystkim w spotkaniach z młodzieżą, natomiast powstałe w wyniku działań organizacji miejsca pamięci mają przypominać następnym pokoleniom o dokonanej zbrodni i piętnie, jakie odcisnęła ona na życiu rodzin.

Według Aleidy Assmann, „Mamy dziś do czynienia nie z samolikwidacją, lecz odwrotnie: z eskalacją zagadnienia pamięci. Bierze się to stąd, że pamięć doświadczenia świadków historii, by jej w przyszłości bezpowrotnie nie utracić, musi zostać przełożona na kulturową pamięć potomnych. Żywa pamięć ustępuje miejsca pamięci wspartej na mediach, która posiłkuje się materialnymi nośnikami, takimi jak pomniki, miejsca pamięci, muzea i archiwa"119. Członkowie Dolnośląskiej Rodziny Katyńskiej świadomi naturalnego stanu rzeczy, jakim jest przemijanie, wciąż starają się pozostawić po swojej działalności namacalny ślad ${ }^{120}$. Największą inicjatywą, podjętą przez stowarzyszenie, było wybudowanie Pomnika Ofiar Katynia. Pomysł ten powstał już podczas pierwszego spotkania rodzin katyńskich w 1989 r., jednak bezpośrednie działania, które miały na celu postawienie we Wrocławiu monumentu, rozpoczęły się w 1994 r. ${ }^{121}$ Uroczyste odsłonięcie oraz poświęcenie Pomnika Ofiar Katynia, który stanął w parku im. Juliusza Słowackiego we Wrocławiu, nastąpiło 22 września 2000 r. ${ }^{122}$ Oficjalnego otwarcia dokonał Andrzej Przewoźnik, natomiast kard. Henryk Gulbinowicz poświęcił monument.

Pozostając przy miejscach pamięci, chciałbym rozwinąć wątek powstania Cmentarzy Wojennych w Katyniu, Charkowie, Miednoje i Bykowni. Kontakt z rzeczywistymi mogiłami ojców wyzwalał i ogromne emocje,

118 Statut Dolnośląskiej Rodziny Katyńskiej, s. 2.

119 A. Assmann, Przestrzenie pamięci. Formy i przemiany pamięci kulturowej, [w:] Pamięć zbiorowa i kulturowa. Wspótczesna perspektywa niemiecka, red. M. Saryusz-Wolska, Kraków 2009, s. 106.

120 Warto wymienić Pomnik Ofiar Katynia w parku im. J. Słowackiego, odsłonięty 22 września 2000 r., dwa Krzyże Katyńskie na cmentarzach komunalnych Grabiszyn i Osobowice wybudowane w 1994 r., Tablicę Katyńską zainstalowaną na ścianie pamięci „Golgoty Wschodu” przy klasztorze OO. Redemptorystów w 1994 r. Więcej zob.: A. Siomkajło, Katyń w pomnikach świata, Warszawa 2002.

121 Sprawozdanie z X-letniej działalności Stowarzyszenia Dolnoślaskiej Rodziny Katyńskiej, złożone na zebraniu ogólnym członków DRK w dniu 20 listopada 1999 roku, s. 5.

122 Sprawozdanie z działalności Rady Stowarzyszenia Dolnoślaskiej Rodziny Katyńskiej w okresie kadencji od 20 września 1997 r. - 9 grudnia 2000 r., s. 6. 
skrywane i kumulowane przez lata ${ }^{123}$. Widok prawdziwego grobu ojca przywoływał wspomnienia z dzieciństwa. Mogę jedynie przypuszczać, co czuły dzieci zamordowanych, które ostatni raz widziały ojca w wieku kilku lat, a przyjeżdżały na jego grób już jako osoby dorosłe, często same będące rodzicami: „Przyjechałam po raz pierwszy na grób ojca, który zginął mając lat 35, a ja tam byłam jako kobieta 54-letnia. Mogłam być jego matką, a nie córką"124. Dzięki nieocenionej pracy tragicznie zmarłego w 2010 r. Andrzeja Przewoźnika, zamordowani Polacy w końcu zostali godnie pochowani, natomiast ich rodziny znalazły miejsce na złożenie kwiatów: „Bardzo zależy mi na tym, żeby co roku jeździć tam do Bykowni, szczególnie we Wszystkich Świętych. Chociaż raz w roku. Posiedzieć tam, popatrzyć na te sosny i mieć tę chwilę zadumy" ${ }^{125}$.

Przedstawione powyżej refleksje skłaniają do zadania kilku pytań badawczych. Ciekawym tematem, który nie został tutaj nawet zasygnalizowany, jest życie rodzin katyńskich po wojnie na uchodźstwie w Wielkiej Brytanii i innych miejscach. Były to rodziny, które z armią Andersa opuściły Związek Sowiecki, ale nigdy już nie powróciły do Polski. Jak postrzegały Katyń? Czy rodziny te, tak samo jak żyjące w Polsce, po wojnie wyczekiwały powrotu bliskiego? Jak interpretowały sprawę Katynia na arenie politycznej? Czy wdowy po zamordowanych również w większości przypadków nie wychodziły ponownie za mąż? Jak wyglądało kultywowanie pamięci o zamordowanym w domu? Czy wśród kolejnych pokoleń, żyjących poza granicami Polski, przekazywana jest pamięć o bliskim? Jakże istotnym i ważnym tematem byłoby porównanie pamięci tych rodzin z pamięcią rodzin

123 Zob.: Super Wizjer - moja mama była bohaterką, odc. 983, reportaż Doroty Pawlak. Jerzy Ziółkowski, syn st. post. Antoniego Ziółkowskiego, zamordowanego przez NKWD wiosną w 1940 w Kijowie, a pochowanego w Bykowni w reportażu stwierdził: „Nie wiedziałem w ogóle, co się ze mną dzieje. Powiem szczerze, nie wiedziałem czy skakać z radości, czy paść na kolana i płakać, naprawdę, bo coś takiego, nawet sobie nie wyobrażałem, że może się człowiekowi w życiu zdarzyć, żeby po 72 latach się dowiedzieć, zobaczyć na własne oczy praktycznie grób ojca”.

124 Relacja Ludmiły Seredyńskiej.

125 Relacja Wandy Milczanowskiej. 
żyjących w Polsce ${ }^{126}$. Jest to temat, który wciąż czeka na swojego badacza. Innym intersującym tematem jest zmieniająca się pamięć o Zbrodni Katyńskiej wśród kolejnych pokoleń wnuków i prawnuków ofiar. Czy te osoby przekazują lub będą przekazywać informacje o krewnym swojemu potomstwu? Jak pamięć o zbrodni będzie ewoluować wśród kolejnych pokoleń? Czy za kilka, kilkanaście lat rodzina katyńska, składająca się obecnie głównie z córek i synów ofiar, będzie miała szanse przetrwać? Takich i innych pytań można postawić więcej. Stwarzają one pole do kolejnych badań i być może zachęcą kogoś do zajęcia się tym tematem.

Reasumując, w życiu tej grupy osób można wyznaczyć kilka fundamentalnych i przełomowych momentów. Wybuch II wojny światowej kończy okres wspaniałego dzieciństwa i wyznacza cezurę ostatniego spotkania z bliskim, który wyruszył na wojnę. Kolejnym przełomem jest niemieckie odkrycie grobów w Katyniu. Kwestia zbrodni powracała wielokrotnie. Dlatego też z czasem rodziny, które uważały propagandę niemiecką za fałsz, musiały przyjąć do wiadomości, że zbrodnia w Katyniu miała rzeczywiście miejsce. Nie wykluczało to jednak poszukiwań bliskiego. Wydaje się, że dopiero potwierdzenie śmierci bliskiego na papierze (które de facto otrzymały w latach 9o.) mogło skłonić rodziny do zaprzestania poszukiwań.

Rodziny, których bliski zaginął po 1940 r., żyły w pewnego rodzaju zawieszeniu. Ich życie pełne było nadziei, ale także smutku i rozczarowania, kiedy z każdym kolejnym rokiem krewny nie wracał do domu. Zapytania kierowane do PCK o los zaginionych rozbudzały przekonanie, że tym razem odpowiedź będzie pozytywna i dająca szansę na spotkanie. Rodziny, które pogodziły się ze śmiercią bliskiego i rozpoczęły nowe życie, nie mogły zapomnieć o piętnie mordu katyńskiego. Ujawniało się ono w różnych formach, najczęściej przy okazji starań o przyjęcie na studia czy o pracę. W końcu przyszło długo wyczekiwane oswobodzenie z jarzma komunizmu. Rodziny rozpoczęły działania mające na celu wyjaśnienie okoliczności zbrodni i uczczenie pamięci ofiar. Założenie stowarzyszenia oraz powstanie federacji było swoistym manifestem wyjścia z ukrycia i z niewoli kłamstwa.

126 Na uwagę zasługuje działalność Centrum Dokumentacji Zsyłek, Wypędzeń i Przesiedleń Uniwersytetu Pedagogicznego w Krakowie. Jego misją jest przeprowadzanie wywiadów ze świadkami historii poszkodowanymi w wyniku działań wojennych. Wśród nich znajdują się Polacy mieszkający poza granicami kraju: w Stanach Zjednoczonych, Australii, Kanadzie, Wielkiej Brytanii, a nawet Izraelu. 
Mimo odkrycia wielu tajemnic Zbrodni Katyńskiej, żyją w Polsce rodziny, które do tej pory nie znają prawdziwych losów swoich ojców. Jednym z najważniejszych nieodkrytych aspektów zbrodni jest tzw. białoruska lista katyńska. Do dzisiaj dysponujemy jedynie przypuszczalną liczbą obywateli polskich zamordowanych prawdopodobnie w więzieniu w Mińsku, a pochowanych najpewniej w masowych grobach w pobliskich Kuropatach. Rodziny zamordowanych nadal nie mogą zapalić znicza na grobie bliskiego. Jedynym marzeniem tych osób jest jeszcze przed śmiercią poznanie prawdy: „Chciałabym jeszcze za życia poznać prawdę”, podkreśla Anna Naczke, 87-letnia córka Aleksandra Morżało, policjanta z Wołkowyska, zaginionego bez wieści w więzieniu NKWD w Grodnie w 1940 r. ${ }^{127}$

Podczas wielogodzinnych rozmów, które przeprowadziłem z córkami i synami zamordowanych Polaków, dało się zauważyć, że mimo upływu lat wciąż w ich pamięci widnieje idealny obraz II RP, okres dzieciństwa, zabawy, nauki, ale przede wszystkim wspólnych chwil spędzonych z ojcem. Mieszkania moich rozmówców, pełne pamiątek poustawianych w widocznych miejscach, przypominają im przeszłość, tę radosną, ale i tę smutną.

Blisko 5o-letni czas fałszowania historii w PRL, szczególnie tej o Zbrodni Katyńskiej, doprowadził do tego, że dzisiaj rodziny bardzo chętnie chcą opowiadać o swoich losach i o tym, jak zbrodnia sowieckiego aparatu bezpieczeństwa wpłynęła na całe ich życie. W pamięci rodzin motyw ojca stanowi główną oś narracji. Rozmawiając z tymi osobami, poruszając tematy wywołujące smutek i łzy, dochodzę do wniosku, że są dumne z tego, że ich ojciec walczył w obronie ojczyzny i pozostał do końca wierny wartościom zawartym w haśle: „Bóg, Honor, Ojczyzna” mimo iż przyszło mu za to zapłacić najwyższą cenę.

Józef Piłsudski powiedział kiedyś: „Naród, który traci pamięć, przestaje być Narodem - staje się jedynie zbiorem ludzi, czasowo zajmujących dane terytorium" ${ }^{{ }_{128}}$. Przyjmując słowa marszałka jako sprawdzian tożsamości, trzeba stwierdzić, że Polacy zdali go wzorowo, nie zapominając nigdy, mimo kłamstw i manipulacji, czym dla Polski był i jest Katyń.

\footnotetext{
127 Relacja Anny Naczke. Zob.: ilustrację 6. Obszerniej o losach policjanta zob.: K. Łagojda, Tropem listy białoruskiej, „Pamięć.pl”, nr 4(25)/2014, s. 29-32.

128 J. Piłsudski, Myśli i wypsknięcia, Warszawa 2010, s. 7.
} 


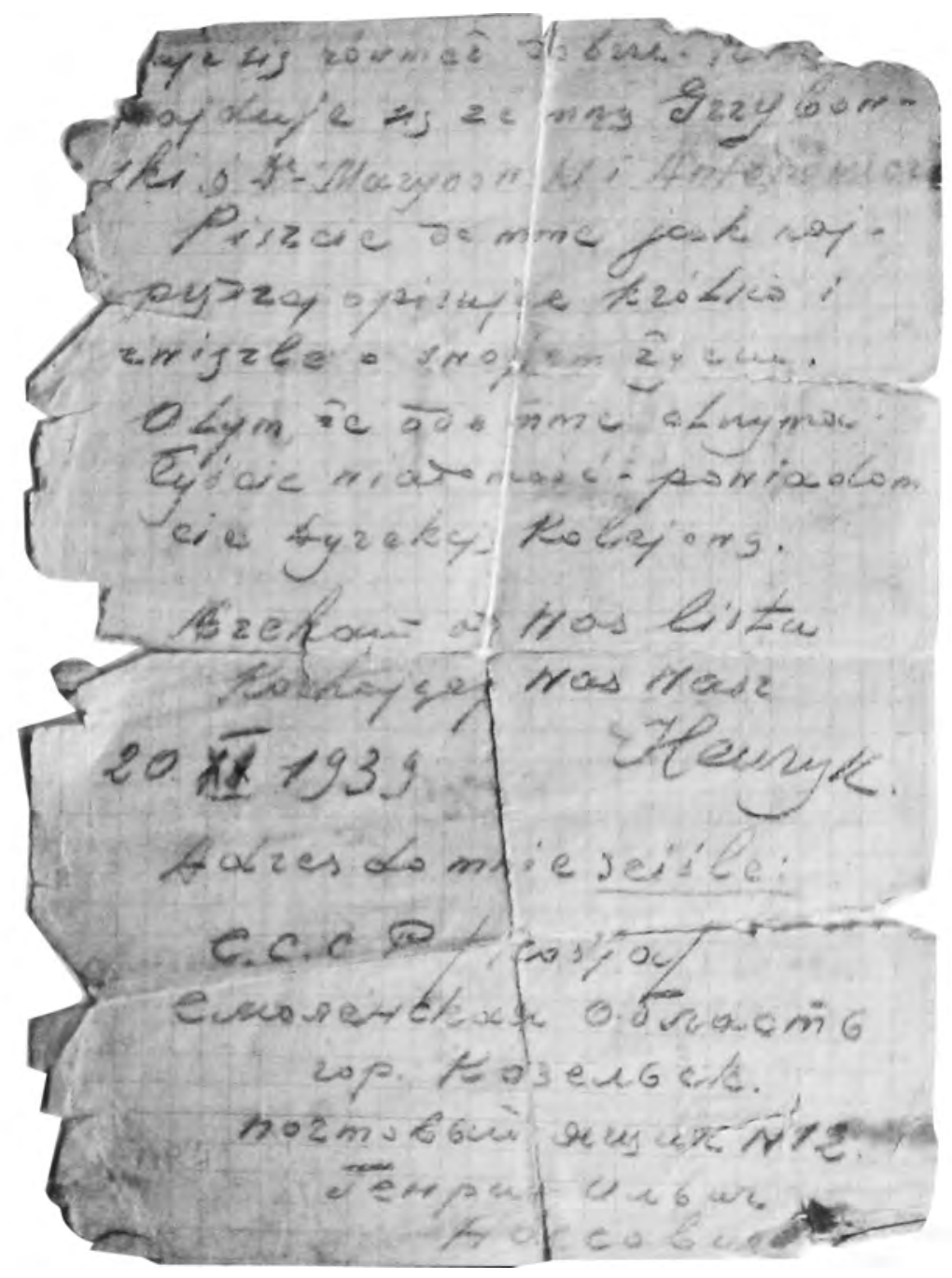

ILUSTRACJA 1

List (gryps) kpt. Henryka Nossowicza z Kozielska, datowany na 21 listopada 1939 r., zawierający adres do korespondencji. (Z prywatnych zbiorów Haliny Strzałkowskiej.) 

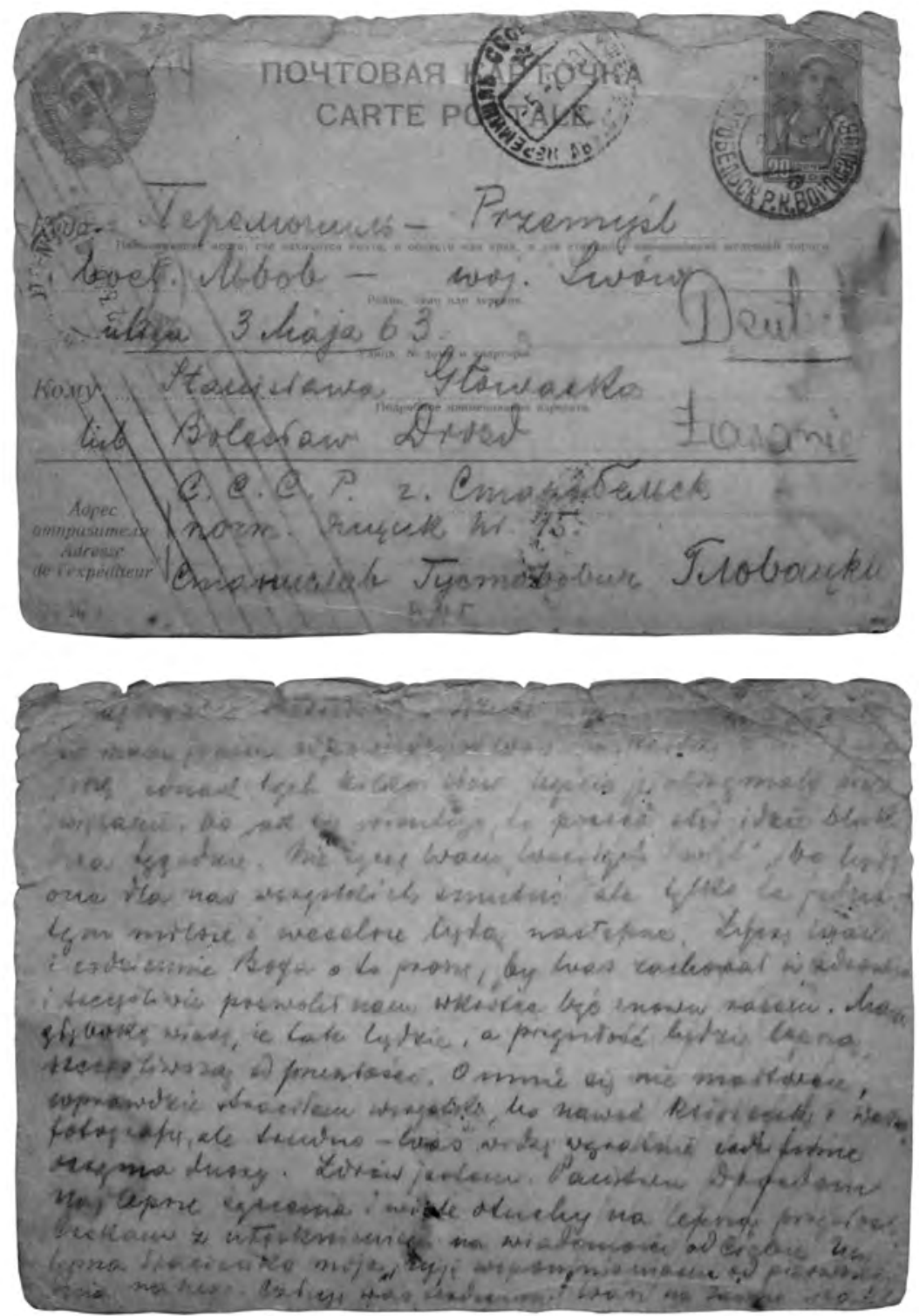

ILUSTRACJA 2

Pocztówka kpt. Stanisława Głowackiego ze Starobielska do rodziny, datowana na dzień 5 lutego 1940 r.

(Z prywatnych zbiorów Aliny Głowackiej-Szłapowej.) 


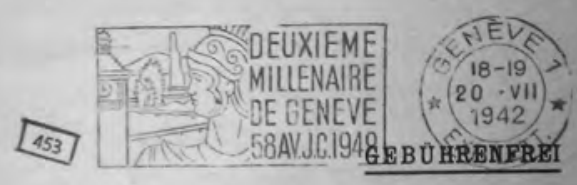

Comité International de la Croix-Rouge

Internationales Komilee vom Roten Kreuz

\section{AGENCE CENTRALE} DES

PRISONNIERS DE GUERRE

GENÈVE (Suisse)

Zentralstelle für Kriegsgefangene GENF (Schweiz)

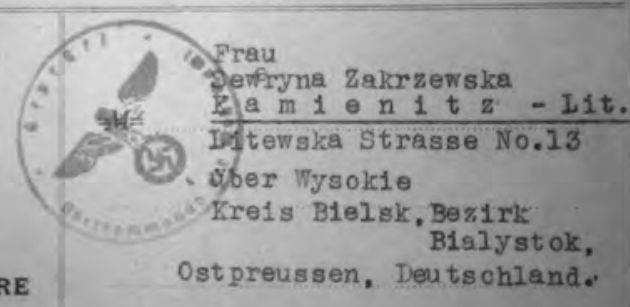

Ostpreussen, Deutschland.

S.INII . P.

$232 \mathrm{e}$

Ref. Nr. DP 37596 (Zakrzewski Genf, (Datum des Poststempels)

DP 37597 (Chełchowski Tadeusz-Narian) $\rightarrow$

AT

Aas Internationale Komitee vom Roten Kreuz bestätigt den

Empfang Ihres Schreibens vom 31.5 .42 .

befreffend 1./ZAKRZEWSII Henryk-Konstanty ,2./CHELCHOW= ski Tadeusz-Marian.

Es wird sich bemühen Ihrem Wunsch nachzukommen und Ihnen Mitteilung machen, sobald eine Nachricht eintrifft.

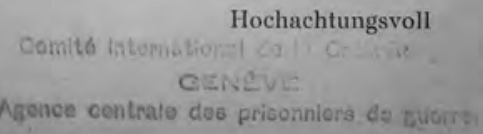

ILUSTRACJA 3

Odpowiedź MCK z dnia 20 lipca 1942 r. na zapytanie Seweryny Zakrzewskiej o miejsce pobytu męża mjr. Henryka Zakrzewskiego oraz brata Tadeusza Chełchowskiego. (Z prywatnych zbiorów Krystyny Gołębiowskiej.) 


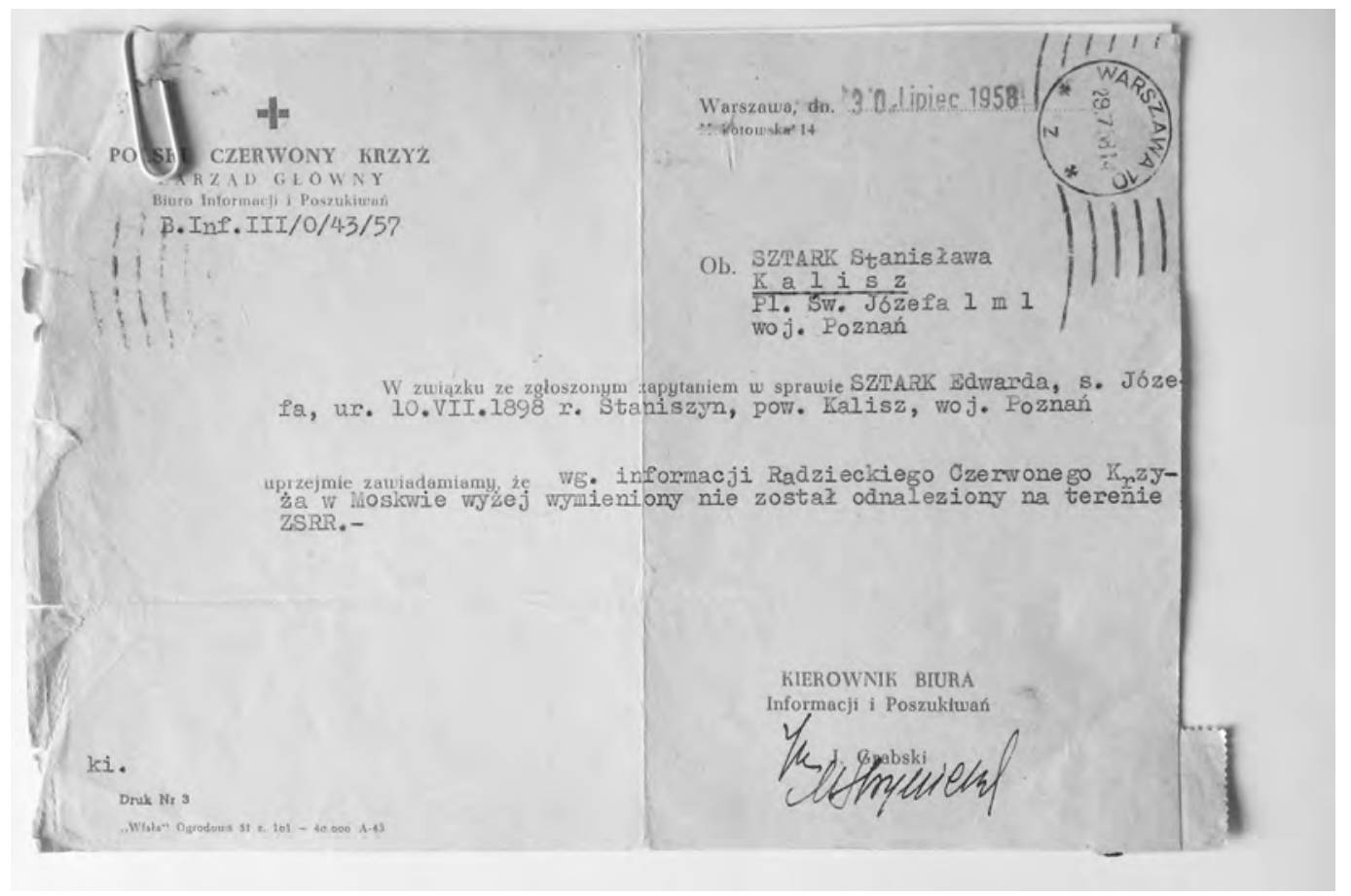

ILUSTRACJA 4

Odpowiedź PCK z dnia 30 lipca 1958 r. na zapytanie Stanisławy Sztark o los męża, por. rezerwy Edwarda Sztarka, zamordowanego w Katyniu. (Z prywatnych zbiorów Barbary Dworzak.) 


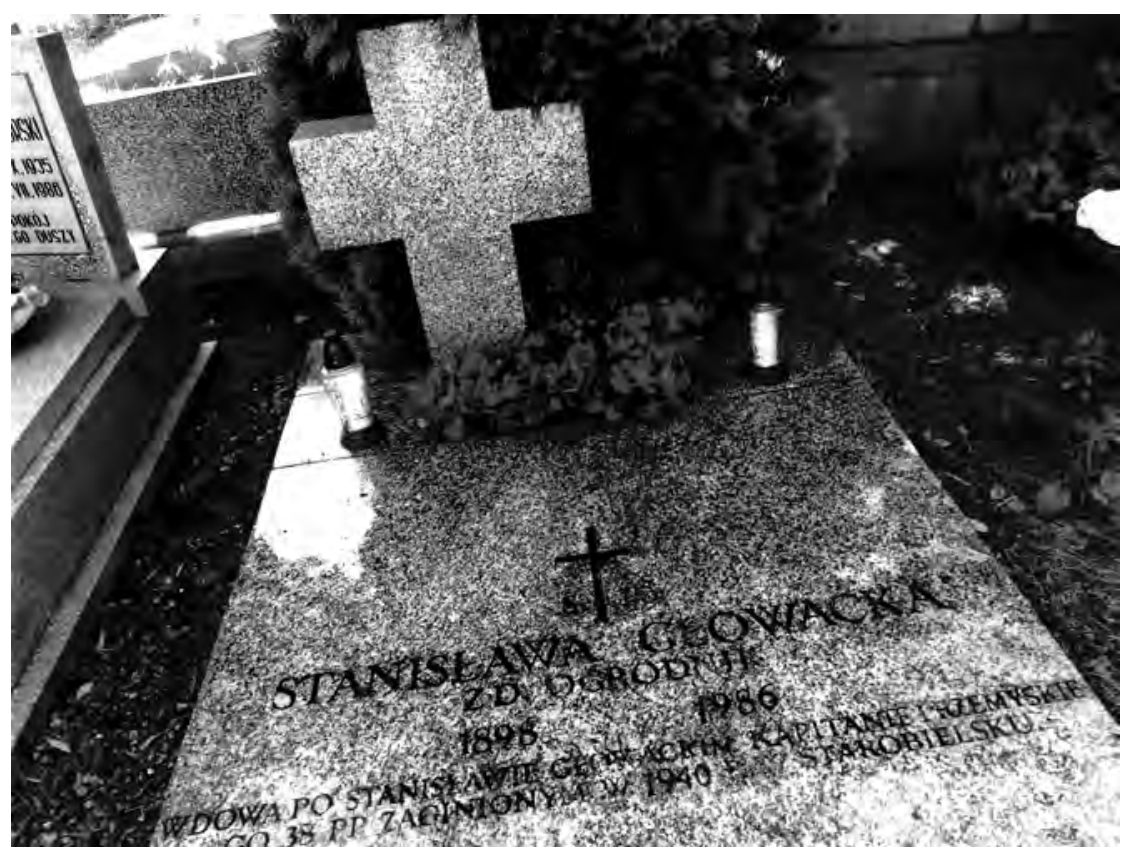

ILUSTRACJA 5

Grób Stanisławy Głowackiej, wdowy po kpt. Stanisławie

Głowackim zamordowanym w Charkowie w 1940 r. Na płycie napisano: „Wdowa po Stanisławie Głowackim kapitanie przemyskiego 38 PP zaginionym w 1940 r. w Starobielsku" Płyta sporządzona w 1986 r. na polecenie córki Aliny Głowackiej-Szłapowej. Grób znajduje się na cmentarzu przy ulicy Smętnej w dzielnicy Sępolno we Wrocławiu (Zdjęcie własne.) 


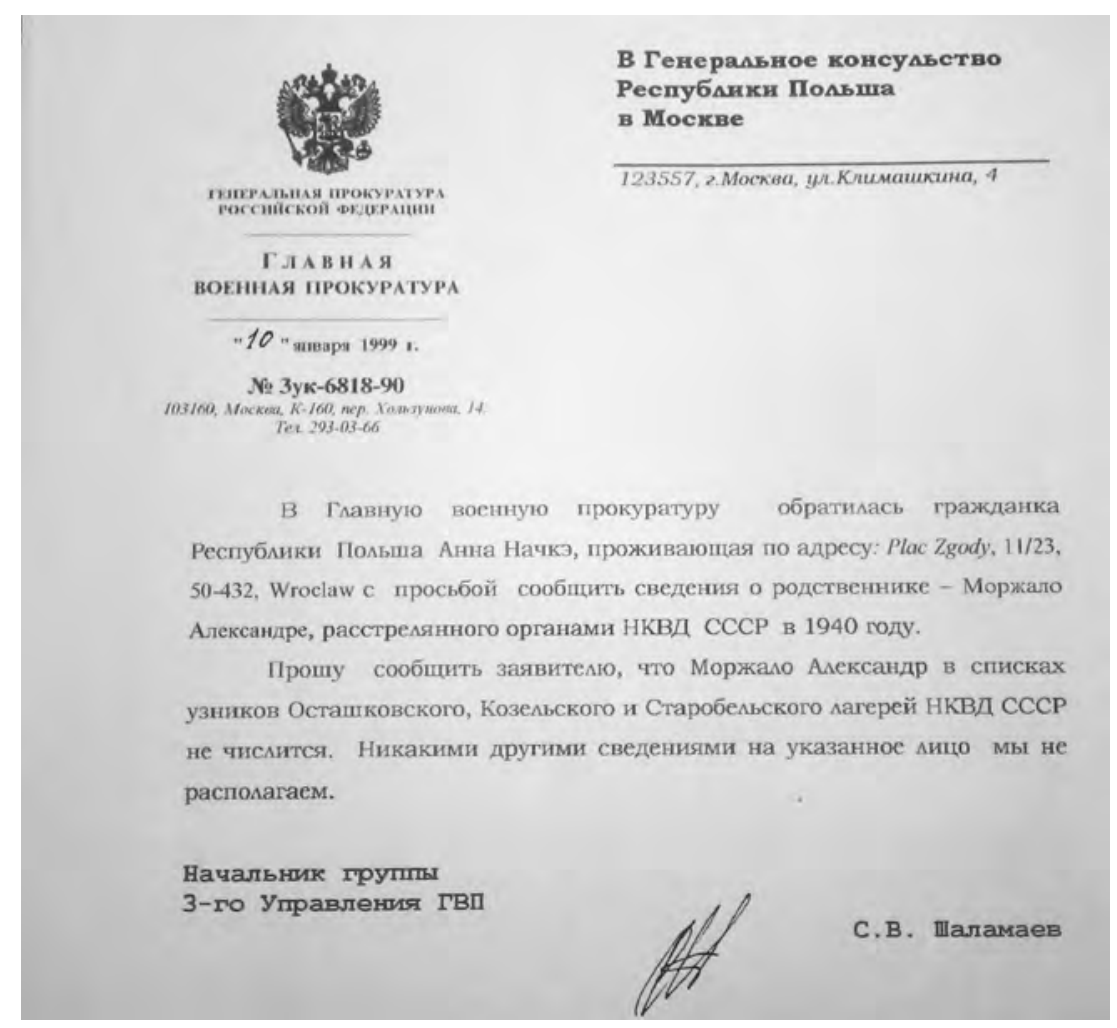

ILUSTRACJA 6

Odpowiedź Głównej Prokuratury Wojskowej z 10 stycznia 1999 r. nadana przez Generalny Konsulat Republiki Polskiej w Moskwie na zapytanie Anny Naczke, córki policjanta Aleksandra Morżało, o los ojca. (Z prywatnych zbiorów Anny Naczke.) 
The article analyzes biographical narrations referring to the daily life of families of the victims murdered by Soviet troops in Katyn and other places in the former USSR. The text includes 12 biographical interviews and recorded memories of Katyn families. The text describes the years from the interwar period to the fall of Communism in Poland. The article describes memories of the Second Polish Republic period when families of Polish officers constituted the highest social class, about the moment of saying goodbye to a father who was setting off to the front and then was taken prisoner by Soviets. Using postcards and letters sent from prisoner-of-war camps, which are attached to the article, the author presents the context of the correspondence of families with their close relatives, the sudden break of this correspondence and the anxiety connected with this lack of messages from the camps. The author carries out a detailed analysis of the process of impossibility of accepting the death of loved ones by their families. The text also addresses the issue of the "Katyn lie" and its influence on the lives of families in the Polish People's Republic, celebrating holidays, their social status after the Second World War and many others. Being aware that the topic is far from being fully described, the author poses a few significant research questions at the end of the discussion that require further analysis.
Krzysztof

Łagojda

Memories of the father. Reflections from interviews with families of Katyn Victims. Research reconnaissance 